\title{
BIOCHAR IN CATTLE FARMING: AN INNOVATIVE SOLUTION FOR SOIL FERTILITY AND CATTLE PRODUCTIVITY
}

\author{
Hana'a Burezq \\ Desert Agriculture and Ecosystems Program, \\ Environment and Life Sciences Research Center, \\ Kuwait Institute for Scientific Research, PO 24885 Safat 13109 Kuwait \\ *Corresponding author - E-mail address haborizq@kisr.edu.kw
}

\begin{abstract}
Biochar as a soil amendment is increasingly popular in agricultural sector in the past few years. The production and application of biochar is increasing in a constant rate to meet farm requirements. Biochar is similar to charcoal and activated charcoal, which are pyrogenic carbonaceous matter derived from organic carbon rich matter through pyrolysis. The primary products generated by pyrolysis are biochar, syngas and bio-oils depending on biomass and pyrolysis conditions. The quality of biochar is according to primary biomass source, pyrolysis temperature and time which ultimately effects on variations in physicochemical properties such as porosity, carbon content, elemental composition, surface area, retention capacity and overall applications. While biochar has been receiving attention as a restorative soil amendment, innovative dimensions for this ultra-porous material are cropping up all over the industrial landscape. In recent times, biochar has been gaining attention in agricultural productivity not as a soil fertility agent, but as an animal feed and animal husbandry applications. Biochar a carbonized biomass similar to charcoal is utilized for treating animals for centuries. An enhanced utility of biochar as cattle feed globally, to improve animal health, increased nutrient intake efficiency and thus productivity. Since biochar is enriched with nitrogen rich organic compounds during the digestion process, the excreted biochar manure acts as a valuable organic fertilizer causing lower nutrient losses and green house gas emissions during storage and soil application. The use of biochar as feed additive has the ability for general body fitness of animals, increased feed efficiency, minimize nutrient losses and greenhouse gas emission, increase the soil organic matter content and thus soil fertility as applied to soil. It can maintain blood cell contents, increase egg, milk and meat productivity and able to resist pathogens in gastrointestinal tract and reduce methane emission from animals. Moreover, the high sorption capacity of biochar removes the pollutants and toxins from the gastrointestinal tract of animals. However, current awareness on effectiveness of biochar in animal production is less, which should be explored more. The challenges such as safety, dosages, contaminations, cost and awareness among farmers need to be addressed. The review highlights the potential benefits of biochar as animal feed in all possible dimensions.
\end{abstract}

KEYWORDS: biochar, charcoal, animals, feed, methane

\section{INTRODUCTION}

\section{Biochar}

Biochar is generated by burning carbonaceous biomass in oxygen-starved combustion conditions through pyrolysis or gasification (Lehmann et.al. 2009). Biochar is produced by pyrolysis of various biomass at temperature ranging from $350^{\circ} \mathrm{C}$ to $1,000^{\circ} \mathrm{C}$ (European Biochar Foundation,
2018 (EBC); International Biochar Initiative (IBI), 2015). Pyrolysis is the thermal deprivation of any waste biomass in a no oxygen atmosphere to produce condensable vapors, gases, and charcoal. The thermal treatment along with the characteristics of biomass yields a charcoal like material with a unique physical structure and chemical makeup. The pyrolysis process yields gas (Carbon di oxide, Hydrogen, Carbon 
Monoxide, and Methane in different ratios), volatile oil, and soil char material (Lehmann 2007). During the charring process, carbon is converted into aromatic structure that are more difficult to break down when compared to the raw material. The ratio of gas, to oil to char depends on the heating conditions applied on the raw material (Sohi et.al. 2020). The composition of biochar (content in carbon, nitrogen, potassium) is proportional to the biomass used, the duration and temperature of pyrolysis. The physicochemical properties of biochar are inclined by the components of biochar and conditions of pyrolysis such as temperature set for pyrolysis and the duration of pyrolysis (Downie et.al. 2009; Kloss et.al. 2012). Various biomass contains dissimilar configuration such as basic components, moisture content, organic and inorganic content, volatile content etc. and therefore, alter the properties of respective biochar (Kloss et.al. 2012). The pyrolysis process causes several alterations in the physical properties such as porosity and surface area and chemical composition such as carbon and hydrogen content (Chan and Xu 2009).

\section{Biochar as activated carbon}

Biochar undergoes an activation process above $850^{\circ} \mathrm{C}$ with water vapour or carbon dioxide with chemical compounds such as phosphoric acid or potassium chloride, and produces activated biochar similar to activated carbon (Hagemann et.al., 2018). The solid phase of pyrogenic process of pure wood results in charcoal; while the solid phase of a broad spectrum of biomass end up in biochar. The activated carbon of biochar and charcoal can be considered as similar pyrogenic carbon materials.

Biochar offers an incredibly vast surface area to capture and hold minute particles, that gives room for microbes as well as to hold undesirable components. Biochar is intended to stay longer in terrestrial environment as they do not decompose rapidly as soil amendment or as any other source. (Schmidt et.al., 2018). As biochar does not involve in rapid mineralization to carbon dioxide, it is considered as a terrestrial carbon sink and therefore very promising for negative emission of carbon dioxide (Werner et.al., 2018). With this excellent quality, biochar has led a tremendous growth in restoring barren soil to fertility, while several other characteristics of biochar rather than soil replenishment has been explored to favour cattle's.

\section{History of Biochar Research}

During the first stage of biochar research, it was suggested as a soil amendment applied to soils in large quantities that increased yield of multitude of crops (Jeffery et.al., 2017). More recently it was explored that blending biochar with other organic amendments such as organic manure, compost and other animal excreta may increase yield significantly (Steiner et.al., 2010; Godlewska et.al., 2017). Biochar is non-toxic and edible and therefore not only blended with manure, but could be included as an input in animal feed (European Biochar Foundation (EBC), 
2012). The incremental addition of biochar to silage and feed demonstrated biochar to be used in cascades. The combination of biochar with fodder minimizes the formation of myxotoxins and butyric acid, removes pesticidal residues and enhances the activity of lactic acid bacteria. (Calvelo et.al., 2014). Biochar blended with straw reduces hoof disease and minimize intolerable odors and nutrient losses (O'Toole et.al., 2016). As biochar is blended with organic components, it is enriched nutrionally with enhanced cation exchange capacity and redox activity, with a decrement in $\mathrm{pH}$ (Joseph et.al., 2013). The interior region of the biochar pores is drenched with organic coatings, while biochar is blended with organic nutrients, increasing the water and nutrient uptake, that improves nutrient recycling thereby enhancing plant growth (Hagemann et.al., 2017; Joseph et.al., 2018; Kammann et.al., 2015; Conte et.al., 2013). The usage of biochar in animal farming system minimizes the environmentally harmful loss of ammonia and nitrate by volatilization and leaching (Liu et.al., 2018; Sha et.al., 2019), with the potential to minimize greenhouse gas emissions such as nitrous oxide (Borchard et.al., 2019) and methane (Jeffrey et.al., 2016). The utility of biochar in cascading especially as animal feed began in 2012 in European countries such as Germany and Switzerland (Gerlach and Schmidt, 2012) and a larger proportion of biochar is been utilised as animal feed, bedding, manure treatment apart from its utility as soil amendment (Schmidt and
Shackley, 2016). In 2016, a new biochar certification standard specifically for animal feed was introduced by the European Biochar Foundation to validate quality control and conformity of European regulations for animal feed (European Biochar Foundation (EBC), 2018). Biochar is reported to improve the nutrient intake efficiency, adsorb toxins and to improve animal health (Toth and Dou, 2016). The review elaborately deals with the current stage of knowledge of biochar as a animal feed additive and the impact of biochar as feed on various livestock, pathogen infestation and on greenhouse emission

\section{Biochar as cattle feed}

Charcoal is a traditional remedy for digestive disorders for human beings and livestock besides medicinal herbs and oils since ages (Derlet and Albertson, 1986). Charcoal is administered as such for animals such as pigs and chicken, but mixed with butter for cows, with eggs for dogs and with meat for cats. In $19^{\text {th }}$ and $20^{\text {th }}$ century, various cow tonics with charcoal as key ingredient along with spices, pepper etc. is advocated to minimize digestive disorders, increase appetite and enhance milk production (Pennsylvania State College, 1905). Charcoal was considered as superior feed additive for enhancing butterfat content of milk of cow (Savage, 1917). Researches by veterinarians on the feeding of activated and non-activated biochar for cattles, revealed its influence in reducing pathogenic toxins from Clostridium tetani and Clostridium botulinum (Skutetsky and 
Starkenstein, 1914). Research on incorporating biochar as animal diet has several benefits. The ecosystem of animal gut is similar to soil, that require a diversity of microbes to digest food and absorb nutrients. Poor gut health of an animal considerably reduces the feed efficiency, with the animal requiring enormous food to meet the nutrient demand of the body. Ruminants are inefficient in digesting and absorbing nutrients compared to other animals and produce enormous methane, where massive energy is diverted, which otherwise should have utilized by the body. The utility of biochar as an additive has shown to increase feed efficiency and increase weight gain of animals through several mechanisms:

Biochar increases the habitat surface area of the gut and enhance the activity of beneficial microbes which work on digestion and cycling of nutrients. The beneficial gut bacteria colonising on biochar feed on gut methanogens, the energy intensive bacteria that produce methane. Biochar also adsorbs the gut toxins such as aflatoxins, which accumulate on hay feed and are stored in the fat of grazing livestock, ultimately is consumed by human beings and other compounds in the digestive tract that severely impact of the animal health and the products they produce (Gerlach and Schmidt, 2014). Biochar powder with molasses in feed of animals, developed a better taste for the cattle's which significantly reduced the total costs of feed, fertilisers and cattle drenching.

\section{Benefits of biochar in animal performance}

Increased feed intake and Weight gain: Biochar a supplementary food increases feed intake and considerably gain the body weight of animals

Improved digestion: Biochar promotes digestion in animals.

Increased immunity: Biochar adsorbs toxins from the digestive track and maintains the balance of microbial activity and avoids subsequent damage to animals' digestive system.

Increased feed and energy efficiency: Biochar addition with chicken diet has shown to improve the adsorption of energy from feed, ultimately improving the efficiency of the feed.

Increased Growth rate: Increased body weight has been documented in broilers fed with biochar.

Higher egg production and quality in poultry: The egg laying ability of chicken was enhanced with the production of highquality eggs.

Improvement of meat quality: The heathy state of animals by biochar feeding improves the quantity and quality of their meat.

Reduction in claw and feet diseases: The claw and foot diseases cause severe economic loss depending on the severity, which causes weight loss, decreased milk production, dry matter intake, herd longevity and reproductive efficiency. Biochar considerably reduces the severity of the 
disease minimizing health impacts and productivity of animals.

Reduction of veterinary costs: Biochar improves the general health of cattle's and thereby productivity. Therefore, the wastage in veterinary costs is considerably minimized.

Reduce Chronic Botulism: Chronic botulism is a lethal disease caused by the ingestion of botulinum neurotoxin is an increasing concern lately. A study revealed the administration of charcoal mix to cows suffering from chronic botulism was found that biochar or charcoal could be a tool in minimizing chronic botulism condition of cows.

\section{Reduced Methane Production:}

Methane is produced by methanogens in the rumen of animals in their natural digestive process called enteric fermentation, which is considered as a major contributor of greenhouse gases. A study suggested that biochar addition in feed provided a habitat for methane oxidation and microbial activity in the rumen, ultimately reducing net methane production (Leng et.al., 2012).

In general, biochar as cattle feed is found to improve health and appearance of cattles, increase the vitality, udder health, and milk production, decrease mortality rate, diarrhea and hoof disease, reduce odour of excreta, and cause post-partum health stabilization. Biochar improves overall health, which speculate in their overall productivity. Biochar excreted as manure maintains soil-restoring properties and enhances soil fertility (Gerlach and Schmidt, 2012).

\section{BIOCHAR AS CATTLE FEED}

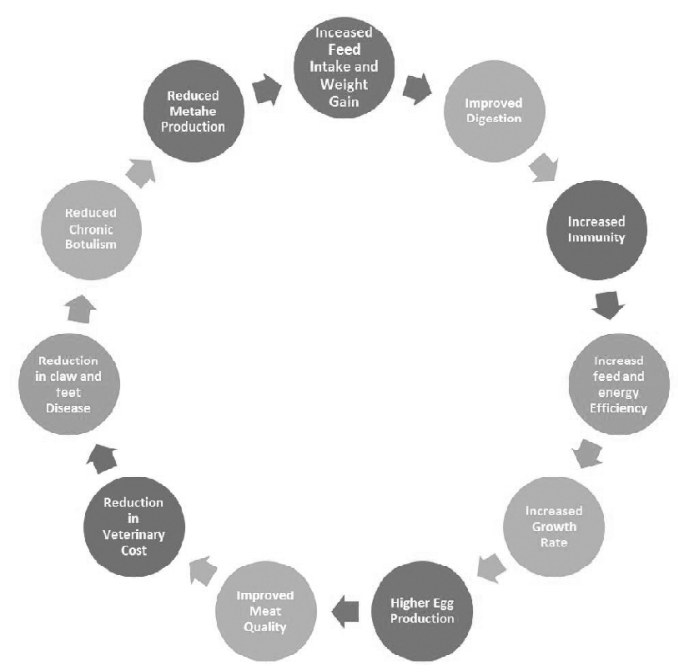

Fig 1. Potential Benefits of Biochar as Cattle feed

\section{Biochar improves hygiene conditions}

Biochar can hold gases and pollutants, as an adsorbent and can improve hygiene in chicken coops or sheep pens and cattle shed. Hygiene in animal shelter is a challenge among producers as huge number of animals in a same shelter with constant contact with their excrement, animal shelter is an easy host for pathogens, creating a breeding ground of infectious bacteria. In addition, ammonia is produced from the excreta, which is toxic and highly odorous resulting in severe adverse effects on the animals (Joseph et.al., 2015). Addition of biochar can significantly reduce $\mathrm{pH}$ of the litter and the emission of the harmful ammonia gas. 
Mechanism of biochar in feed digestion

\section{Adsorption}

Charcoal is considered as a veterinary drug for emergency treatment of animals for centuries for indigestion and poisoning (Decker and Corby, 1971; Hagenamnn et.al., 2018). Biochar, which is a charcoal from different feed stocks due to its high adsorption capacity is utilized for detoxification of diverse toxins such as mycotoxins, plant toxins, pesticides as well as toxic metabolites or pathogens. Biochar as a non-digestible sorbent is an important adsorption therapy for preventing harmful or fatal effects of orally ingested toxins (McKenzie 1991; McLennan \&Amos, 1989). Mechanism of adsorption by biochar includes selective adsorption of some toxins like dioxins, co-adsorption of toxin containing feed substances, adsorption followed by a chemical reaction that destroys the toxin and desorption of earlier adsorbed substances in later stages of digestion (Gerlach \& Schmidt, 2012). Adsorption of proteins, amines, aminoacids, digestive tract enzymes, as well as adsorption of bacterial exoenzymes, binding of mobile germs via chemotaxis occurs as the effects of biochar on bacteria and their toxins in the gastrointestinal tract of animals. The endotoxin release by gram negative bacteria can be minimized if colonized with biochar as the toxins were adsorbed by the colonized biochar. Biochar exhibits 'enteral dialysis, where the adsorbed toxins can be removed from blood plasmas the adsorption power of the huge surface area of the biochar interacts with the permeability properties of intestine (Schirrmann, 1984). Biochar interrupts the enterohepatic circulation of toxic substances between the intestine, liver and bile and prevents compounds such as estrogens, progestogens, digitoxin, organic mercury, arsenic compounds, and indomethacin from being taken up in bile. Toxins secreted by intestine such as digitoxin and toxins passively diffuse in intestine such as pethidines is adsorbed. Moreover, compounds that diffuse along concentration gradient between intestinal blood and primary urine will be adsorbed (Liu et.al., 2012).

\section{Redox reactions}

Biochar, apart from adsorption of toxic substances have a pivotal function of redox activity. Biochar is also considered as geoconductors or batteries that have the ability to accept, store and mediate electrons for from and for biochemical reactions (Sun et.al., 2017). Biochars produced under high pyrolysis temperature of more than $600^{\circ} \mathrm{C}$ are excellent electron conductors, while biochars produced under low pyrolysis temperature such as $400-500^{\circ} \mathrm{C}$ function as geobatteries as they hold phenol and quinone surface groups (Yu et.al., 2015) and therefore, both high and low temperature biochars can mediate electrons and actin biotic and abiotic redox reactions (Sun et.al., 2017; Kappler et.al. 2014). Biochar can accept and donate electrons and can act as anode and cathode in microbial cells in the intestinal tract (Nevin et.al., 2010; Konsolakis et.al., 2015). The electrical 
conductivity of biochar is not continuous electron flow but a discontinuous electron hopping or electron shuffle facilitating even inter-species electron transfer (Kastening et.al., 1997). The electron transfer capacity of biochar lead to long distance transfer that intends a spatially more extensive accessibility to alternative electron acceptors such as minerals for anoxic microbial respiration due to comparatively large size of biochar particles (Chen et.al., 2015; Sun et.al., 2017). The microbial decomposition of organic compounds in the gastrointestinal tract, particularly anaerobic rumen, involves electron transfer, where an electron acceptor is required to get rid of surplus electrons that accumulate during the degradation of organic molecules. Microorganisms depend on the availability of both an electron donor and acceptor to which surcharge electrons can be transferred, as electrons do not exist in a free state under ambient environmental conditions and cannot be stored in large enough quantities by cell. This redox reaction where molecules or atoms that donate an electron are coupled through electro-chemical reactions with molecules or atoms that accept an electron should takes place in close proximity (Bhatt et.al., 2012). The coupling of electron donating and accepting reactions is mediated by electron mediators, that can take up an electron from a chemical reacting molecule, microorganism, solid interphase and provide it to another molecule, atom or solid phase or microorganisms. Electron mediating compounds such as thionine, tannins, methylene blue, quinone show comparable capacities to biochar and humic substances (Van Der Zee et.al., 2003; Klupfel et.al., 2014). A well-balanced animal feed should contain several electron mediating substances, whereas the high energy animal feeds available in market are insufficient in electron mediators (Sophal et.al., 2013). The addition of inert and nontoxic electron mediators such as biochar, paves way for several redox reactions increasing the fed efficiency (Liu et.al., 2012). Biochar either act as sole mediator or a synergistic mediator that uplifts the efficiency of other mediators (Kappler et.al.,2014).

The feed degradation reactions in the gastrointestinal tract of animals are facilitated by microorganisms, where bacterial cells transfer electrons to biofilms or through biofilms to other terminal electron acceptors (Ritcher et.al., 2009). However, biofilms are very poor in electron mediation, while biochars have an electrical conductivity of 100 to 1,000 times than biofilms. Biochar contains minerals such as iron and manganese that can electrically support microbial growth by acting as an electron sink for heterotrophy-based respiration, as an electron source for autotrophic growth, by enabling cell to cell transfer of electrons and as an electron storage material (Shi et.al., 2016). It is clear that enabling extracellular electron transfer contributes to a more energy efficient digestion resulting in higher feed efficiency. Moreover, the electron transfer between biochar and microorganisms could be the 
main reason for reduced methane emission by cattles (Prasai et.al., 2016).

\section{Mechanisms of Specific Toxic Adsorption}

\section{Detoxification of mycotoxins}

Mycotoxin contamination on cereal crops and fodder is estimated to be more than 25 percent according to Food and Agriculture Organization (FAO) (Mezes et.al., 2010). The contamination due to this mold fungi occurs under field as well as storage conditions (Wild et.al., 2015). The most destructive mycotoxin groups to living organism are aflatoxins B1 (AFB1), deoxynivalenol (DON), zearalenone (ZEN) and ochratoxin A (OCHRA) (Keller et.al., 2012). Due to prolonged feeding of contaminated feed, farm animals are prone to serious health ailments notably immunosuppressive disorders, carcinogenic and mutagenic effects, gastrointestinal discomforts leading to reduced production (Ankul et.al., 2013; Misihairabgwi et.al., 2017). The contaminated animal products such as milk, milk based processed foods, egg, meat etc. transmit the mycotoxins to human beings (Sobrova et.al., 2010). The incorporation of adsorbents such as biochar, activated carbon and non-charcoal adsorbents such as zeolites, bentonites and aluminosilicates have promising results in minimizing the toxic level in animal blood stream (Dakovic et.al., 2005; Huwig et.al., 2001). The total surface area and pore size distribution influences the adsorption capacity of biochar to bind the mycotoxins and reduce the bioavailability and thereby improves animal productivity (Galvano, 2001). The addition of $2 \%$ activated biochar to pelleted aflatoxin-spiked feed for dairy cows declined the extractable aflatoxin concentration in animal feed by 74 per cent and concentration in milk by 45 per cent (Galvino et.al., 1996). In another investigation, the mycotoxins ochratoxin $\mathrm{A}$ and deoxynivalenol by 0.8 to 99.86 percent and 98.93 percent respectively were adsorbed by biochar depending upon the biomass used (Galvino et.al., 1996). The activated biochar showed 99 percent absorbance of aflatoxin B from a 0.5 per cent aflatoxin B-spiked solution dosed at $1.11 \mathrm{~g}$ on $100 \mathrm{ml}$ (Diaz et.al., 2002). The mechanism behind detoxification of mycotoxin is the ability of activated biochar to adsorb the toxic metabolites due to its high specific area in combination with a favourable micropore size distribution and the high affinity of toxins for their polyaromatic surface (Di Natale et.al., 2009). A comparative study on natural biochar and synthetic adsorbent feed additives on minimizing aflatoxin content of milk revealed a higher toxin reduction capacity of 90 percent with $0.5 \mathrm{~g}$ aflatoxin per $\mathrm{kg}$ of diet. with positive effects on milk composition with regard to organic acids, lactose, chlorides and protein content (Di Natale et.al., 2009). The adsorption capacity of activated biochar at four different doses 0.5,1.0, 1.5 and 2.0 per cent for a dangerous metabolite, zearalenone, for Fusarium sp. showed a positive response in binding the toxin (Bueno et.al., 2005). An analogous 
investigation of Holstein dairy cows fed at 0,20 or $40 \mathrm{~g}$ daily with activated biochar had higher feed intake and improved digestibility of neutral detergent fiber, hemicellulose and crude protein (Ericson et.al., 2011). In a similar study with Holstein cow breeds, a 65 per cent aflatoxin reduction was noticed when supplemented with 0.25 per cent activated charcoal (Diaz, 2004).

Similar findings were reported in goats as well. The aflatoxin level in goat milk has reduced to 76 percent when supplemented with 1.0 percent activated biochar for 2 weeks (Rao et.al., 2004). Biochar addition to aflatoxin B1 contaminated goat feed reduced the toxin (100 pb) to milk by 76 per cent, which was significantly higher than that of bentonite (65.2 percent) (Naumann et.al. (2013). The experimental supplementation of lethal doses of aflatoxin with activated biochar observed no significant indication of internal organ damage, the possible reason being the inability of aflatoxins to be absorbed in goat intestines (Hatch et.al., 1982). Mycotoxins cause liver damage in kidney of poultry; while biochar administered with 0.02 per cent body weight significantly increased the activity of key liver enzymes (Dalvi and Ademovero, 1984). In an investigation aflatoxin at $10 \mathrm{ppm}$ reduced feed intake and body weight of broilers, while 0.1 per cent biochar addition reversed the trend (Dalvi and McGowan, 1984).

\section{Detoxification of bacterial pathogens}

The utility of activated and nonactivated charcoal to adsorb bacterial toxins of Clostidium tetani, Clostridium botulinum and diphtheria as well was practiced since olden days (Jacoby, 1919). A daily supplement of $400 \mathrm{~g}$ of high temperature biochar pyrolyzed at $700^{\circ} \mathrm{C}$ minimized the antibodies of Clostidium botulinum in the blood of cattles symbolizing a suppression of the infection. Moreover, the neurotoxin in gastrointestinal tract of insects was reduced as well (Gerlach et.al., 2014). A reduced cell count of below 800 from 5.33 x $10^{6}$ by five $\mathrm{mg} / \mathrm{ml}$ of Escherichia coli was noticed when injected with activated charcoal, fed for sheep (Knutson et.al., 2006).

The mechanisms associated with minimizing bacterial activity is linked to the physical chemical properties of biochar and the microbial status in the gastrointestinal tract. A study revealed the addition of $5 \mathrm{~g} / \mathrm{ml}$ of activated charcoal in feed can minimize the levels of Escherichia coli and Salmonella to the minimum level of $10 \mathrm{mg} / \mathrm{ml}$ as the combination of pore size and its diameter in binding these microscopic bacterial organisms (Naka, 2001). Moreover, the increased activity of beneficial microbes viz., Bifidobacterium, Enterococcus and Lactobacillus in the gastrointestinal tract is also noticed. The improved activity of the beneficial bacteria colonize the gut environmental niches and with the competitive exclusion principle as they outweigh pathogenic population (Callaway et.al., 2012). Biochar as strong adsorption or suppression capacity of gramnegative bacteria with high metabolic 
activity. The E.coli count in the faeces of sheep fed with 0.25 percent activated biochar or 0.50 per cent coconut tree biochar was lower than in the control without biochar and the beneficial bacteria, Lactobacillus increased in both biochar treatments (Kim et.al., 2017).

The cattle manure will contain E.coli, which can contaminate soil and water an eventually harm human beings by entering the food chain (Die-Gonzalez et.al., 1998). Biochar can adsorb E.coli and its metabolites in the animal digestive tract as well as minimize is spread in the environment by adding it to the manure(Gurtler et.al., 2014). The soil columns blended with $2 \%$ biochar reduced E.coli and Salmonella enterica count in the manure (Abit et.al., 2012). The prophylactic addition of biochar to cattle trough water minimizes spread of E.coli infection, as it spread through water sources among cattle herds. The mixture of 1 percent bamboo biochar and 1.5 per cent bamboo vinegar reduced and Salmonella level in chicken excrement (Watarai and Tana, 2005). NekkaRich, a patented biochar product showed a significant reduction of Salmonella in chicken droppings (Besnier, 2014). A biochar-wood vinegar combination reduced the Enterococcus facecium bacteria in the gastrointestinal track of chicken (Wataraj and Tana, 2005).

\section{Detoxification of pathogenicity of other organisms}

The activity of cattle rotavirus and coronaviruses can be reduced at 79-99.99 percent by addition of biochar or clay (Clark et.al., 1998). The binding of viral particles occurs due to the greater diameter of biochar and clay and the viral surface proteins binding to biochar. Biochar in combination with wood vinegar was able to control parasitic protozoa Cryptosporidium parvum infection and stop diarrhoea of calves. The oocytes in the faeces dropped significantly the next day of biochar feeding and no more oocytes after 5 days of feeding (Watari et.al., 2008). Analogous results of reduced diarrhoea were obtained as a commercial biochar wood acetic acid product was investigated as a feed additive in goats. The mortality of goats is significantly reduced by 20 per cent (Paraud et.al., 2011). Biochar supplementation to goats also reduce the incidence of parasites such as cestode tapeworms and Coccidia oocysts (Van et.al., 2006).

\section{Detoxification of drugs}

The use of activated carbon (biochar) to treat human poisoning is practiced since 1980's (Erb et.al., 1989). The adsorbing ability of biochar to prevent gastrointestinal uptake of most drugs and numerous toxins, is more effective than pumping out stomach contents (Neuvonen and Olkkola, 1988). The repetitive intake of activated carbon or biochar improved the elimination of overdosed drugs such as aspirin, carbamazepine, dapsone, dextropropoxyphene, cardiac glycosides. A faster elimination of any environmental and industrial toxins was assessed due to activated biochar intake. The activated 
biochar was administered at a rate of 50$100 \mathrm{~g}$ for adults and $1 \mathrm{~g} / \mathrm{kg}$ of body weight for children. The repeated oral administration of biochar increases the efficacy of detoxification (Crome et.al., 1977).

Detoxification of pesticides, organic pollutants and environmental toxin

The residues from pesticides (insecticides, herbicides, fungicides, nematicides), heavy metals (lead, arsenic, chromium, mercury, cadmium, chromium), organic pollutants (polycyclic aromatic hydrocarbons, sulfamethoxazole) pose a serious threat to animals (Pandey and Madhuri, 2014; Uchimiya et.al., 2012). These toxic metabolites emanate from air, water, plants, soil etc and bioaccumulate in human beings as well as animals (Schwarzenbach et.al., 2010). The accumulation of the toxins leads to formation of toxic soluble compounds in animal bodies causing detrimental effects (Pandey and Madhuri, 2014). Biochar is reported to have properties of adsorption and serve as a feed additive to detoxify toxins from environment, which is increasingly found in animal feed (Mandal et.al., 2017; Safaeri et.al., 2016; Borchard et.al. (2019).

Glyphosate, the herbicide currently contaminates most of the feed produced from genetically modified maize, rapeseed and soybean and suspected to cause or promote chronic botulism (Shehata et.al., 2012). Biochar as feed additive detoxifies glyphosate residues at low $\mathrm{pH}$ and high temperature of pyrolysis (Herath et.al., 2016; Hall et.al., 2018). In an investigation with 380 dairy cows feeding with humic acid (120g/day), biochar (200g/ day) for 4 weeks significantly reduced glyphosate concentration in cow urine fed with glyphosate contaminated silage (Gerlach et.al., 2014). Activated biochar showed invitro adsorption abilities on the residues of the banned herbicide Paraquat (Okonek et.al., 1982; Gaudreault et.al., 1985). The pesticide adsorption of biochar is reported since 1970's in cattle's, goats, sheep etc. and were eventually excreted (Wilson and Cook, 1970; Humphreys and Ironside, 1980). The deposits of the organophosphorus insecticide Runnel in Sheep were reduced by feeding the sheep with 50 activated biochar per keg of feed (Smalley et.al., 1971). Feeding of biochar for pigs reduced accumulation of the organochlorine insecticide, Dieldrin in their fats (Dobson et.al., 1971). The addition of activated biochar at $900 \mathrm{~g}$ per animal reduced Dieldrin and DDT level by 43 and 24 per cent respectively (Wilson et.al., 1971). Numerous fat-soluble organochlorine compounds such as Dibenzo-p-dioxin (PCDDs), Dibenzofuran (PCDFs) and dioxin like PCBs are ubiquitous in the environment and detected in animal feed and accumulate in the adipose tissue of human beings and animals causing detrimental effects. Biochar has strong affinity for organochlorine residues according to several researches (Yoshimura et.al., 1986; Kamimura et.al., 2009; Iwakirir 
et.al., 2007). An extensive research with 24 egg laying hens with their feeds containing organochlorine compounds and 0.5 per cent biochar for 30 weeks reduced the concentration of PCDDs/PCDFs, non-ortho PCBs and mono-ortho PCBs in the eggs and tissues of chicken by 90,80 and 50 per cent respectively (Fujita et.al., 2012). Toxic compounds with higher aromaticity have stronger affinity to biochar and thus regular feeding of biochar as feed supplement can eliminate industrial and environmental toxins from cattles.

\section{Detoxification of plant derived toxins}

Plants produce several kinds of toxins as a protective means, apart from thorns, spines and prickles to deter any kind of physio biological disturbances (Wittstock and Gershenzon, 2002). Those toxins such as tannins are beneficial to plants but have detrimental effects on the herbivores consuming it, resulting in injuries, illness and even death (Strusaker et.al., 1997). Tannins are secondary compounds that are beneficial as well as harmful to ruminants. Tannins are high protein feeds such as legumes, the strong taste repels animals, reducing digestibility and weight gain (Naumann et.al., 2013). An investigation by feeding goats with $50-100 \mathrm{~g}$ bamboo biochar per $\mathrm{kg}$ of a tannin rich Acacia leaf diet gained weight by 17 per cent in comparison to control without biochar (Van et.al., 2006). A mixture of 10-25 $\mathrm{g}$ of activated biochar per day increased the tannin and terpene uptake in ryes (Banner et.al., 2000). Similar results were reported for Sage based biochar fed to lambs significantly reduce terpenic and tannin-rich shrubs (Rogosic et.al., 2006; 2009) The bitterweed (Hymenoxys odorata DC) is a favourite feed of sheep that contain toxic levels of sesquiterpene lactones. A research feeding trial of 0.5 to $1.5 \mathrm{~g}$ of biochar per lamb per day mixed to feed, revealed a 26.4 $\%$ increased feed intake without signs of toxicosis. The toxins present in Lantana camara, an invasive weed, can be detoxified when treated with $5 \mathrm{~g}$ of biochar per $\mathrm{kg}$ body weight of cattles (Mc Lennan and Amos, 1989). The pore network, surface area and surface acidity of biochar adsorbs the plant-derived toxins ingested by cattle in the gastrointestinal tracts of animals. Investigations have revealed that the micropores of less than $2 \mathrm{~nm}$ pore size tend to have lower adsorption rate due to reduced diffusion of these toxic compounds. However, biochar with pore space between 2-50 nm, increased adsorption efficiencies are experienced (Galvano 1996). Nevertheless, the overall efficiency depends on numerous factors such as physicochemical characteristics of activated charcoal, amount of charcoal supplemented as feed, concentration of toxin in feed, species and animal breed (Bansal and Goyal, 200; Kim, 2006). The present literature on promising results of biochar in detoxifying plant toxins are listed in Table 1.

\section{Improved performance of farm animals by biochar supplementation}

Biochar is utilized to enhance crop production by enriching soil fertility in 
general, while it has several qualities. Up to 90 percent of produced biochar is utilized by various treatments including treatment of slurry, as feed additive, as a litter component, compost production, silage production, in fish farming to treat polluted water (Gerlach and Schmidth, 2012). The farm animals such as cattles, sheep, goat, pig and poultry have given promising results with biochar as feed supplement to enhance their health and performance.

\section{Cattles}

Biochar is widely used as a regular feed supplement in cattle farming all around the world especially European countries (European Biochar Certification body, 2018). Regular feeding of $100-400 \mathrm{~g}$ of high temperature wood biochar per cow per day has reported to increase the overall health and vitality without any negative side effects. The somatic cell count of the milk from cattle fed with biochar decreases which is an indicator of the number of harmful bacteria, while the milk protein and fat content increased, while the somatic cell count increases as the cattle cease's biochar feeding. Moreover, the hoof disease troubles decreased and post-partum health of cattle's improved due to biochar feeding. As cattle's initiated biochar feeding diarrhoea symptoms reduced and the faecal matter become firmer as biochar is a constituent. In addition, mortality rates declined and the overall veterinary cost of cattle production has reduced with increased milk productivity (Gerlach and Schmidt, 2012). The rice hullderived biochar at 0.6 percent fed biochar resulted in 25 percent higher weight gain compared to control animals (Leng et.al., 2013). A feed supplement of 1 per cent rice husk biochar added to basal diet of cassava root, urea, rice straw and fresh cassava foliage increased by weight gain by 15 per cent and feed conversion rate also improved by 15 per cent as well (Phongphanith and Preston, 2018). The high temperature biochar fed at $0,0.5,1.0$ and 2.0 per cent to high forage diet for 7 continuous days in a semi-continuous artificial rumen system increased the digestion of dry matter, organic matter, crude protein and fiber as well as the microbial protein synthesis, acetate, propionate and total volatile fatty acid production by microbials in the artificial rumen (Saleem et.al., 2018). Biochar is not only utilized to improve cattle health performance but also to increase the nutrient availability of manure, thereby to clean ground water and sequester soil carbon. Biochar in the digestive system of cattles capture organic and mineral compounds with enhanced fertilizing properties, which would be leached otherwise. These captured nutrient compounds remain bound in biochar until reach the soil (Mc Henry, 2010; Kammann et.al., 2015; Schmidt et.al., 2017).

\section{Goats and Sheep}

Similar to cattle, investigations were done with goats and sheep fed with biochar and successful results were obtained. Feeding of one gram of bamboo biochar for 42 young goats for 12 weeks increased body weight by $53 \mathrm{~g}$ per day compared to 
$44 \mathrm{~g}$ in control and increased the crude protein content intake (Van et.al., 2006). In a study, goats fed biochar and tannin rich acacia (Acacia magnum) leaves, eased digestion of those leaves by adsorbing tannins, which increased the crude protein content (Kim and Kim, 2005). A basal diet of tannin rich Bauhinia acuminata leaves with 1 per cent biochar improved nutrient assimilation and led to 27 per cent increase in weigh gain per day in a continuous observation for 100 days (Silivong and Preston, 2016). A feeding study of different levels of biochar at $0,0.5,1.0$ and 1.5 per cent in goat ration with concentrate and forage increased dietary protein digestion and dry matter intake at 0.5 per cent (Phonpanith et.al., 2013). In another investigation, a goat feed additive of 1.5 and 3 per cent activated coconut biochar showed negative effect as they did not produce significant improvement of feed nor microbial activity, whereas increased the faecal concentration of decomposable carbohydrates with reduced faecal $\mathrm{N}$, leading to beneficial slowdown in the mineralization rate of organic carbon in the manure, which enhance soil organic matter built up (Al-Kindi et.al., 2017).

\section{Pigs}

Biochar provides health benefits to pigs as reviewed for cattles, goats and sheep. A feeding experiment of piglets supplemented with biochar and woody vinegar (1:4) at 0,3 and 5 per cent of feed revealed an increased weight gain and feed utilization efficiency (Mekbungwan et.al.,
2004). Pigs fed with bamboo biochar at $0,0.3$ and 0.6 per cent along with the normal fattening diet containing corn, wheat, soybean meal for 42 days showed an average weight gain of $877 \mathrm{~g}$ per day in 0.3 percent fed pigs, corresponding to 17.5 percent increase in feed efficiency while it was $750 \mathrm{~g}$ per day in control. A reduction in susceptibility to stress is marked with positive effect on total protein, albumin and cholesterol levels, while different blood cells such as erythrocytes, leucocytes, haemoglobin and platelets did not differ significantly (Chu et.al., 2013c). In another investigation feeding of 0.3 and 0.6 per cent bamboo biochar enhanced marketable meat and composition of pig fat with an upsurge in unsaturated fatty acid content and down surge in saturated fat (Chu et.al., 2013b). In a similar investigation, feeding 0.3 percent bamboo biochar gave the same growth rate in fattening pigs as the standard antibiotic treatment without any harm to the ecosystem (Chu et.al., 2013a). With several feeding trials it was concluded that biochar varies with the rate of biochar supplement, the primary source of biochar, the length/ duration of feeding experiment (Chu et.al., 2013). An experiment with pigs supplemented with $0,0.3$ and 0.6 per cent biochar revealed that improved carcass characteristics, live weight gain and immune response at 0.3 per cent supplementation (Choi et.al., 2012). The meat quality, meat color traits and tenderness of meat is enhanced by biochar treatment (Lee et.al., 2011). 


\section{Poultry}

A systematic study with poultry fed with two different biochars with corn cobs and Canary tree (Bakeridesia integerrima) seeds at 0 and 1 percent per $\mathrm{kg}$ revealed high ash content of 47 and 25 per cent respectively indicating that a substantial portion of initial biomass is burned and not pyrolyzed with increase in weight gain, liver weight, abdominal fat and bowel length (Kana et.al., 2010). In a subsequent study, chick peas which is an excellent protein diet but difficult to digest was added with biochars at 20 percent rate and found the broilers to digest chickpeas easily with a weight gain (Kana et.al., 2012). Inclusion of citrus wood charcoal at $0,2,4$, and 8 per cent supplemented to standard broiler feed showed 2 percent increase in body weight, feed intake and feed efficiency (Bakr et.al., 2007). Addition of a very high dosage of 10 per cent biochar to the basal broiler feed for 28 days achieved weight gain and feed efficiency (Kutlu et.al., 2001). Several feed trials in chicken and turkey, achieved positive results for 0.2 percent hardwood biochar with higher weight gain, better feed efficiency, higher protein levels in pectoral muscles and lower mortality rate, which is due to the detoxification of feed components, reduction in surface tension of digestive pulp and improvement in fat loss in liver. (Majewska and Pudvszak, 2011; Majeswska et.al., 2009; Majewska et.al., 2002). A similar study by Ruttanavut et.al., (2009) with ducks fed with 1 per cent biochar and wood vinegar blend showed significant effect in villi size, cell surface, rate of cell division in the gut, which was in line with studies by Samanya and Yamauchi, (2001) and Ruttanawut, (2014). An experiment with 150 young ducks fed with 1 per cent 1:1 mixture of biochar and sea tangle (Laminaria japonica) can be utilized as an alternative to the use of antibiotics in duck feeding (Islam et.al. 2014). Apart from enhanced health performance of broilers, biochar has the potential to bind antinutritional factors in the feed (Kutlu, 1998). Moreover, studies that involve laying hens, biochar inclusion to improve quality and quantity of eggs were investigated. The number of cracked eggs due to thin and unhealth egg shells laid by chicken is considerably reduced when fed with 1-4 per cent biochar supplemented with feed compared to contro, fed without biochar (Kutlu et.al., 2001). Feed supplement of 1 per cent mixture of carbonaceous biochar and woody vinegar showed an increment in member collagen by more than 33 per cent (Yamauchi et.al., 2010). Increased egg production and egg shell strength have been observed when diet is supplemented with biochar (Kim, 2006; Yamauchi et.al., 2013). A study on ducks with $0.1,0.5$ and $1.0 \mathrm{p}$ er cent of diet composed of seaweed and control diet with antibiotic Chlorotetracycline showed better feed efficiency and can suggested as potential alternate for antibiotic (Islam et.al., 2014). Several researches on quality of chicken meat due to biochar supplement were experimented and positive results were 
obtained (Cai et.al., 2011; Kim et.al., 2011; Yamauchi et.al., 2010). The broiler chickens fed with 1 per cent biochar increased useful fatty acid, oleic acid and total mineral content of meat (Park and Kim, 2001). On the other hand, supplementation of 2 per cent bamboo biochar with wood vinegar did not show difference in meat quality (Sung et.al., 2006; Ruttanawut 2014). Several studies on biochar supplementation on egg shell was studied and a positive effect was s noticed (Kutlu et.al., 2001; Kim et.al., 2006; Yamauchi et.al., 2010). Diet supplementation of bamboo biochar and vinegar at 5 percent increased egg production with collagen content of eggs increased significantly by 33 per cent. Collagen increase the shell life of eggs and they is an important ingredient of pharmaceuticals and cosmetics (Yamauchi et.al., 2013).

\section{Reduction of methane emission}

Livestock accounts for 81 per cents of the greenhouse gases emitted in the environment (Hristov et.al., 2013). Decomposition of the solid and liquid excretion of ruminants cause greenhouse gas emissions by direct gaseous excretions through flatulence and burping. Livestock is capable of producing 200- 500 litre of methane per day (Johnson and Johnson, 1995). The methane emissions produced by rumen microbial methanogenesis are responsible for 90 per cent of greenhouse gases caused by cattle (Tapio et.al., 2017). The methanogenesis is carried out in bovine rumen by archaea that convert microbial digestion products $\mathrm{H}_{2}, \mathrm{CO}_{2}$ or formate $(\mathrm{HCOOH})$ to methane for energy gain under anoxic conditions. Hydrogen serves as electron donor for microbial reduction of carbon di oxide to methane, while reduction of formate requires several biochemical pathways. Methane production cause a significant loss of energy from 2 to 12 per cent of total energy intake, as high energy methane cannot be digested and has to be eliminated by burp or flatulence from digestive tract (Murray et.al., 1976). Methane is 28 to 34 times more harmful than carbon di oxide, there is an increasing concern in feed supplements that not only increase feed efficiency, but also minimize methane emission due to methanogenesis (Myrhe et.al., 2013). Biochar act as electron acceptor and reduce methane production in rumen (Leng et.al., 2012). Inclusion of 0.5 and 1 per cent biochar addition to the ruminal liquid significantly reduced methane production. When urea is replaced by nitrate in the feed methane production is reduced by 49 per cent. Both, biochar and nitrate act as electron acceptor in the rumen and reduce methane production by 29 and 22 percent respectively constituting a total 49 per cent (Saquing et.al., 2016). Invitro biochar addition of 1 per cent with manioc root feed nix decreased methane emission by 7 per cent (Phanthavong et.al., 2015). Investigations by Leng et.al., (2012) found that rumen fluid from cows that had been fed with biochar produced less methane than non-biochar fed cattle. The biotic reduction of nitrate through Methylomirabilis oxyfer- 
like bacteria with supplements nitrate as oxygen source for methane oxidation in rumen. Denitrifying anaerobic methane oxidizing bacteria like Candidatus methylomirabilis oxyfer is shown to efficiently oxidize methane anaerobically in deep lake segments (Deutzmann et.al., 2014).

Leng et.al., (2013) suggested the methane formation in cattles could be reduced by 20 per cent when 0.6 per cent of biochar was included with the normal diet invivo experiments. With the addition of 6 per cent potassium nitrate reduced methane emission by 40 per cent. An increased bovine weight gain in addition suggesting an increase in feed efficiency and reduction in energy conversion losses was noticed (Leng et.al., 2013). The biochar in the invivo experiments were produced from silicon rich rice husks at high temperature $\left(900^{\circ} \mathrm{C}\right)$, which has high electrical conductivity and electron buffering capacity, with greater efficiency of fodder decomposing redox reactions (Yu et.al., 2015; Sun et.al., 2017). Studies reveled that different biochars have differences in electrical conductivity and in electron buffering, that depends on biomass, pyrolysis temperature that determine the biochars properties of transmitting electrons between different bacterial species. (Sun et.al., 2017). Biochar produced from wood or straw tend to reduce methane emission from 11 to 17 percent in an invitro study (Hansen et.al., 2012). Cabeza et.al., (2018) investigated the effects of invitro rumen gas production and fermentation characteristics of two different temperatures 550 or $700^{\circ} \mathrm{C}$ from five different biomass sources viz., straw, oilseed rape straw, rice husk and wheat straw considerably reduced methane production.

There are some contradictory results reported by Winders et.al., (2019) that biochar supplement at 0.8 and 3 per cent did not detect any significant reduction in methane emission over a $23 \mathrm{~h}$ period. Calvelo et.al., (2014) found biochars from pinewood chips and corn stover pyrolyzed at 350 and $550^{\circ} \mathrm{C}$ co-fermented with ryegrass silage did not have any effect on methane production. The probable reasons are yet to be explored.

An investigation on high temperature biochar on artificial semicontinuous rumen system, that was post pyrolytically treated to acidify the biochar to $\mathrm{pH}$ of 4.8 , fed with a high-forage diet of $0.5,1$ and 2 per cent reduced methane production by 34, 16 and 22 per cent respectively. Biochar acidification oxidizes the carbonaceous surfaces to make biochar hydrophilic and modifies the redox behaviour and its affinity for microbial interaction (Saleem et.al., 2018). The acidification of biochar not only oxidizes the carbonaceous surfaces and makes the biochar hydrophilic; it also modifies the redox behaviour and thus its "affinity" for microbial interaction. Research in the acidification of biochar is too lacking to draw a conclusion; but it is suggested that post-pyrolytic treatment of biochar has the ability to optimize the biochar effects in 
digestion of animals to reduce methane emission. Moreover, the application of biochar to manure through feeding or bedding material acts as a potent strategy to reduce manure related greenhouse gas emission. Biochar prepared from wood shavings pyrolyzed at $650^{\circ} \mathrm{C}$ was applied at 13 per cent to a cattle slurry and subsequently applied at $3.96 \mathrm{~m}^{3}$ biochar ha${ }^{1}$, biochar decreased total $\mathrm{NH}_{3}, \mathrm{~N}_{2} \mathrm{O}$ and $\mathrm{CH}_{4}$ emissions by 77, 63 and 100 per cent respectively (Kammann et.al., 2017).

\section{Side Effects of Biochar}

According to literature review biochar as a feed supplement or veterinary treatment has not shown any toxic or negative effect on animals or the environment. A growing number of farms utilize biochar for feeding their livestock on a daily basis without noticing side-effects (Kammann et.al., 2017). However, very few reports on longterm feeding of biochar leading to clinical follow-ups (Struhsaker et.al., 2017). The key risks due to biochar feeding arise from shifting microbial species composition in the digestive system and the potential adsorption of essential feed compounds or drugs (Olkkola and Neuvonen, 1989). The adsorptive capacity of activated biochar for beneficial microflora in the digestive tract of cows examined using gram-positive, Enterococcus faecium, Bifidobacterium thermophilum and Lactobacillus acidophilus showed that the adsorption of dangerous pathogens was significantly in higher rate than the beneficial flora (Naka et.al., 2001). However, a systematic investigation and mechanical understanding for a large number of digestive and pathogenic microorganisms before a conclusion is drawn.

\section{Biochar Administration and Quality Control}

Biochar is restricted to use without a complete analysis of entire nutritive parameters of current feed regulations as provided by European Biochar Feed Certificate, carried out by an accredited laboratory specialized in biochar and feed analytics (European Biochar Foundation (EBC, 2018). Moreover, biochar should be processed and administered moist to avoid formation of dust (European Biochar Foundation (EBC), 2012). Feed quality biochar is advocated to be added with drinking water, in case of acute toxification, advised to be administered in aqueous solution (Neuvonen and Olkkola, 1988). Biochar can be provided in freely accessible troughs on pasture or in stable, without previous mixing into daily feed (Joseph et.al., 2015b). Biochar can be administered by mixing with feed supplements such as molasses, humic acid, wood vinegar, nitrate or tannins or flavouring such as saccharin, sucrose (Cooney and Roach, 1979). Injection of 1 percent biochar into silage towers or silage bales through automated equipment was experimented by few German and Swiss scientists (O'Toole et.al., 2016).

The adsoptivity of biochar depends on the specific surface area, charge and pore 
size distribution. Biochar activation significantly increases the specific surface area $\left(300 \mathrm{~m}^{2}\right.$ to $\left.900 \mathrm{~m}^{2}\right)$, which is due to micropore opening $(<2 \mathrm{~nm})$, which are too small for higher molecular weight substances or bacterial pathogens relevant for animal digestion. Biochar with high micro porosity had lower adsorption capacities for mycotoxins as well as pesticide residues and toxins due to slow diffusion of these toxins into pore-system (Galvano et.al., 1996). In addition, activated biochar should not reduce the toxic effects as compared to non-activated biochar (Edrington et.al., 1997). Biochar with high content of accessible meso and macro pores can be achieved merely by adjusting the pyrolysis parameters. A high meso-porosity is achieved at pyrolysis temperatures above 600oC (Brewer et.al., 2014). Biochar activation and acidification can greatly modify the electron mediating capacity, while pyrolysis temperature is the main driver of redox behaviour revealing temperature between 600 and $800^{\circ} \mathrm{C}$ (Sun etal., 2017; Chen and McCreery, 1996).

Biochar can be produced out of a variety of feedstock, some of which can be agricultural residues such as wheat and rice straw (Naeem et.al. 2017; Sun et.al. 2019), cashew nut shell nuts (Abderahim et.al. 2018), peanut shell ( $\mathrm{Xu}$ et.al., 2018) coconuts shells (Devenas et.al. 2018), waste wood (Pituya et.al. 2016), rice husk (Dunninghan et.al. 2018), empty fruit bunch (Baker et.al. 2015), wheat straw (Xu et.al. 2018; Vaccari et.al. 2011), orange peels (Sial et.al. 2019), olive pomace (Ghouma et.al. 2017) and other residues ( Saleh et.al. 2014; Mandal et.al. 2004; El Hanandeh 2015; Chen and $\mathrm{Xu} 2009$;). The biomass energy crops like corncobs (Demirbas 2003), tobacco stems (Peservi et.al. 2010), rice residues (Saleh et.al. 2014), common reed (Komulainen et.al. 2008; Kitzler et.al. 2012), vine prunings (Nasser et.al. 2014), wood pellets (Vaughn et.al. 2013), palm oil and oilseed rape (Zainal et.al. 2016), date palm midribs (Nasser 2014), bioenergy residues (Asfaw 2018), compost (green residue), animal manure (sheep, chicken) (Burezq 2019), sewage sludge, etc. (Sohi et.al. 2010) also have contributed their role in biochar production across the globe. However, no scientific preference over another is documented. The European Biochar Certificate (EBC), a voluntary standard has been managing the certifying biochar quality as animal feed, which guarantees compliance with all feed limits prescribed by EU regulations and certifies sustainable, climate friendly production (European Biochar Foundation (EBC), 2018).

\section{Challenges of biochar utilization in farm animals}

\section{Adequate Research and contradictory findings}

The knowledge of biochar as a feed supplement is limited, with the finding contradicting each other is a great concern to promote biochar as a feed supplement. With the current findings in small-scale, short duration and invitro conditions, it is 
essential for the scientific community to conduct experiments invivo for extended period of time with different climatic conditions, temperature, different species and group of animals and biochar from various biomass. The role of biochar in regulating E.coli was contrasting with different authors and hence extended research in wide areas is required to draw specific conclusions on biochar as a potential feed supplement (Knutson et.al., 2006; Naka, 2001).

\section{Specificity of Biochar}

Biochar produced from diverse feed stock has assorted potentials in feed efficiency, adsorption of toxins, enhancing beneficial microflora in the gastrointestinal tract, which need to be explored. The specificity of biochars in different utilities as feed supplement should be scientifically analysed. A comparative study on evaluating the effectiveness of different adsorbents in regulating different groups of mycotoxins observed a specificity effect of biochar in mollifying these toxic metabolites (Huwing et.al., 2001).

\section{Potential Contaminations}

The Pyrolytic production of biochar accumulates toxins in the end product depending upon the biomass utilized in biochar production. The heavy metals present in the biomass from industrial byproducts such as sewages, will not get volatilized when pyrolyzed and remained as ash component and some hazardous contaminants including dioxins and polycyclic aromatic hydrocarbons are often produced during pyrolysis. Dioxins are produced when the biomass contains chlorine pyrolyzed at $450-850^{\circ} \mathrm{C}$ (Shibanoto and Yasuhara, 2007). These toxins can range from toxic to carcinogenic and mutagenic often associated with shorter residence time and low pyrolysis temperature. Therefore, it is necessary to evaluate the biomass sources and applying optimum conditions during pyrolysis to minimize the risks.

\section{Farmers' Awareness}

Though there were promising findings of biochar with diverse applications, there still exists a knowledge gap of the end-users. There is contrasting practical applications as well as the level of interest by farmers and other stakeholders, environmental managers on global scale. More than 90 per cent of the biochar produced in Europe are utilized for agro-environmental activities such as livestock husbandry, crop production and environment modulation, while it is different for most developing countries. Farmers have misapprehension that all biochars have same physicochemical characteristic, while application rate, periodic interval of application are yet to be clarified. Thus necessary practical initiatives such as establishment of best-use biochar application protocols and programs in educating farmers through extension and livestock field officers.

\section{Farm productivity of biochar}

The commercially produced biochars are highly priced and scarcely available in 
the market. The average cost of biochar in the market is 2.87 US dollar per kilogram (Guo et.al., 2016). The low-cost production of desirable biochar from locally available biomass is restricted due to high production cost and lack of technology in many developing countries. Since abundance of inexpensive raw materials are locally present, Governments need to attract investments in commercial biochar production by local industries, with rural employment can be enabled. The biochar research findings supported by economic analysis, improves awareness for decision making for farm utility of biochar through regulations and safety standards.

\section{Biochar in Kuwait}

Kuwait Biochar Initiative (KBI) has been launched in Kuwait in 2019 and registered as sustaining member at International Biochar Initiative. The KBI was initiated with the current understanding about soil constraints as well as cattle related constraints affecting agriculture production, and the current investment in agriculture is not keeping the pace. The rationale behind the KBI is to have agricultural crop and animal intensification with more productive, sustainable production systems that save on water and inputs and are less harmful to the environment, leading to enhanced food security and sequester carbon. Despite the usefulness of biochar, it is the reality that biochar is used by insignificant number of farmers, globally. Same is the case in Kuwait, where, the use of biochar is still at its beginning. The proposed KBI, has set up its vision for an educational outreach to Kuwait farming community, to save inputs through biochar use to intensify agriculture for food security from animals and crops. Through KBI well thought mission, it will help in providing a platform to potential biochar stakeholders, to support safe and economical use of biochar. We Promise to reach farmers in Kuwait to educate and transfer Biochar technology in the next 4-5 years through a strategic plan starting from idea generation to farmers adoption. Preliminary research and efforts at Kuwait Institute for Scientific Research for the creation of Kuwait Biochar Initiative (IBI) and linking to International Biochar Initiative (IBI), has led to the biochar testing at small farms developed on sandy soil to increase $55 \%$ fresh alfalfa yield compared to control where biochar was not used (Burezq 2019). Research on biochar as cattle feed is in progress with different kind of animals. This preliminary research has given hope to increase local production under critical conditions like COVID 19 which affected food supply chain in many countries including GCC countries, and introduce KBI model to small farms in Arab and developing countries for crops intensification

\section{CONCLUSION}

The ability of biochar to hold minute particles is proving itself more than a soil amendment with benefits of improved digestion, increased immunity, overall health, capabilities in improving hygiene, 
biochar is likely to gain a stronghold in animal husbandry. The current review highlighted the role of biochar in promoting the health and performance of farm animals. The carbonaceous materials are potentially safe and promising feed additive in improving animal performance and can potentially utilized as a substitute for antibiotics. Their prominent role in regulating mycotoxins, bacterial toxins, plant-based toxins, potent pollutants such as heavy metals, organic pollutants and residues from pesticides and herbicides is crucial for the safety of animals, which in turn reflected in health performance indicators by weight gain, immunity response, feed intake, feed conversion rates, carcass characteristics and overall quality of animal products. Further research is urgently needed to unravel the mechanisms underlying the results to optimise biocharbased feeds, which applies to biochar characterization, where analysis is insufficient. The electrochemical interaction of biochar and organic systems are extremely complex and needs considerable fundamental research and systematic trials. In addition, biochar's role with animal digestion is mediator of carrier substance for which the combination of feed additives and inoculants are essential to achieve full functionality of biochar for its beneficial role in animal digestion and health. There is an emerging need to emphasize the establishment of local-based protocol and recommendations for farmers to improve the utilization of biochar for different purposes such as crop productivity, animal husbandry and environmental intonation. Though studies have indicated the improved animal performance with biochar supplementation, more potential research studies were required to verify the underlined mechanisms. With the advancement in current technology, there is a need for more investigation on biochar effectiveness.

\section{REFERENCES}

1. Abderahim, A., N. Alfredo, D. Noel \& M. Didier, 2018. High Physical Properties of Biochar Issued from Cashew Nut Shell to Adsorb Mycotoxins (Aflatoxins and Ochratoxine A) and its Effects on Toxigenic Molds. Engineering and Technology. International Journal of Medical and Health Sciences. 12: 472.

2. Abit S.M., C.H. Bolster, P. Cai \& S.L. Walker, 2012. Influence of feedstock and pyrolysis temperature of biochar amendments on transport of Escherichia coli in saturated and unsaturated soil. Environmental Science \& Technology, 46(15):8097-8105. doi: $10.1021 /$ es300797z.

3. Al-Kindi A., A. Schiborra, A. Buerkert \& E. Schlecht, 2017. Effects of quebracho tannin extract and activated charcoal on nutrient digestibility, digesta passage and faeces composition in goats. Journal of Animal Physiology and Animal Nutrition, 101(3):576-588. doi: 10.1111/jpn.12461.

4. Anukul, N., K. Vangnai \& W. Mahakarnchanakul, 2013. Significance of regulation limits in mycotoxin contamination in Asia and risk management programs at the national level. J. Food Drug Anal., 21 (3), pp. 227-241.

5. Asfaw, G. \& M. Chandraratne, 2018. Biochar Production from biomass Waste-Derived Material. 10.1016/B978-0-12-8035818.11249-4. 
6. Baker, R., R. Ab, A. Zahidah, J. Siti, L. Bahi \& M. Chintsong, 2015. Influence of Oil Palm Empty Fruit Bunch Biochar on Floodwater $\mathrm{pH}$ and Yield Components of Rice Cultivated on Acid Sulphate Soil under Rice Intensification Practices. Plant Production Science. 18: 491-500. 10.1626/pps.18.491.

7. Bakr, B.E.A., 2007. The effect of using citrus wood charcoal in broiler rations on the performance of broilers. An-Najah University Journal for Research, 22:17-24.

8. Banner, R.E., J. Rogosic, E.A. Burritt \& F.D. Provenza, 2000. Supplemental barley and charcoal increase intake of sagebrush by lambs. Journal of Range Management, 53(4):415-420. doi: 10.2307/4003753.

9. Bansal, R.C. \& M. Goyal, 2005. Activated carbon adsorption. CRC press.

10. Bhatta, R., M. Saravanan, L. Baruah \& K.T. Sampath, 2012. Nutrient content, in vitro ruminal fermentation characteristics and methane reduction potential of tropical tannin-containing leaves. Journal of the Science of Food and Agriculture, 92(15):2929-2935. doi: 10.1002/jsfa.5703.

11. Borchard N., M. Schirrmann, M.L. Cayuela, C. Kammann, N. Wrage-Mönnig, J.M. Estavillo, T. Fuertes-Mendizábal, G. Sigua, K. Spokas, J.A. Ippolito, J. Novak, 2019. Biochar, soil and land-use interactions that reduce nitrate leaching and $\mathrm{N} 2 \mathrm{O}$ emissions: a metaanalysis. Science of the Total Environment, 651:2354-2364. doi: 10.1016/ j.scitotenv.2018.10.060.

12. Borchard, N., M. Schirrmann, M.L. Cayuela, C. Kammann, N. Wrage-Mönnig, J.M. Estavillo, T. Fuertes-Mendizábal, G. Sigua, K. Spokas, J.A. Ippolito \& J. Novak, 2019. Biochar, soil and land-use interactions that reduce nitrate leaching and $\mathrm{N}_{2} \mathrm{O}$ emissions: a metaanalysis. Science of the Total Environment. 2019;651:2354-2364. doi: 10.1016/j.scitotenv.2018.10.060.

13. Brewer, C.E., V.J. Chuang, C.A. Masiello, H. Gonnermann, X. Gao, B. Dugan, L.E. Driver, P. Panzacchi, K. Zygourakis \& C. Davies,
2014. New approaches to measuring biochar density and porosity. Biomass and Bioenergy, 66:176-185. doi: 10.1016/ j.biombioe.2014.03.059.

14. Bueno, D.J., L. Di Marco, G. Oliver \& A. Bardón, 2005. In Vitro binding of zearalenone to different adsorbents. Journal of Food Protection, 68(3):613-615. doi: 10.4315/0362-028X-68.3.613.

15. Burezq, H., 2019. Intensification of Alfalfa (Medicago sativa $\mathrm{L}$.) forage production using biochar, animal manure and specialty chemicals - Case of Kuwait. European Journal of Scientific Research, 154, 254-268

16. Cabeza, I., T. Waterhouse, S. Sohi \& J.A. Rooke, 2018. Effect of biochar produced from different biomass sources and at different process temperatures on methane production and ammonia concentrations in vitro. Animal Feed Science and Technology, 237:1-7. doi: 10.1016/j.anifeedsci.2018.01.003.

17. Cai, K.Z., S.T. Jiang \& Y.J. He, 2011. Effects of bamboo charcoal including vinegar liquid on growth performance and meat quality in Chinese indigenous breed during fattening. Journal of Animal and Veterinary Advances, 10(18):2470-2473. doi: 10.3923/ javaa.2011.2470.2473.

18. Callaway, T.R., T.S. Edrington, R.B. Harvey, R.C. Anderson \& D.J. Nisbet, 2012. Prebiotics in food animals, a potential to reduce foodborne pathogens and disease. Rom. Biotechnol. Lett., 17 (6), p. 7809

19. Calvelo Pereira, R., S. Muetzel, M. Camps Arbestain, P. Bishop, K. Hina \& M. Hedley, 2014. Assessment of the influence of biochar on rumen and silage fermentation: a laboratory-scale experiment. Animal Feed Science and Technology, 196:22-31. doi: 10.1016/j.anifeedsci.2014.06.019.

20. Calvelo Pereira, R., S. Muetzel, M. Camps Arbestain, P. Bishop, K. Hina \& M. Hedley, 2014. Assessment of the influence of biochar on rumen and silage fermentation: a laboratory-scale experiment. Animal Feed Science and Technology, 196:22-31. doi: 
10.1016/j.anifeedsci.2014.06.019.

21. Chen P \& R.L. McCreery, 1996. Control of electron transfer kinetics at glassy carbon electrodes by specific surface modification. Analytical Chemistry, 68(22):3958-3965. doi: 10.1021/ac960492r.

22. Chen, S., A.E. Rotaru, P.M. Shrestha, N.S. Malvankar, F. Liu, W. Fan, K.P. Nevin \& D.R. Lovley, 2015. Promoting interspecies electron transfer with biochar. Scientific Reports, 4(1):143. doi: 10.1038/srep05019.

23. Chen, K.Y. \& Z.H. Xu, 2009. Nutrient properties and their enhancement. In: Lehmann J, Joseph S (eds) Biochar for environmental management: science and technology. Earthscan, London, pp. 67-84.

24. Choi, J.S., D.S. Jung,J.H. Lee, Y.I. Choi \& J.J. Lee, 2012. Growth performance, immune response and carcass characteristics of finishing pigs by feeding stevia and charcoal. Korean J. Food Sci. Anim. Resour., 32 (2), pp. 228-233.

25. Chu, G.M., C.K. Jung, H.Y. Kim, J.H. Ha, J.H. Kim, M.S. Jung, S.J. Lee, Y. Song, R.I.H. Ibrahim, J.H. Cho, S.S. Lee \& Y.M. Song, 2013a, Effects of bamboo charcoal and bamboo vinegar as antibiotic alternatives on growth performance, immune responses and fecal microflora population in fattening pigs. Animal Science Journal, 84:113-120. doi: 10.1111/j.1740-0929.2012.01045.x.

26. Chu, G.M., J.H. Kim, S.N. Kang \& Y.M. Song, 2013b. Effects of dietary bamboo charcoal on the carcass characteristics and meat quality of fattening pigs. Korean Journal for Food Science of Animal Resources. 33(3):348-355. doi: 10.5851/kosfa.2013.33.3.348.

27. Chu, G.M., J.H. Kim, H.Y. Kim, J.H. Ha, M.S. Jung, Y. Song, J.H. Cho, S.J. Lee, R.I.H. Ibrahim, S.S. Lee \& Y.M. Song, 2013c. Effects of bamboo charcoal on the growth performance, blood characteristics and noxious gas emission in fattening pigs. Journal of Applied Animal Research, 41(1):48-55. doi: 10.1080/ 09712119.2012 .738219 .
28. Clark, K.J., A.B. Sarr, P.G. Grant, T.D. Phillips \& G.N. Woode, 1998. In vitro studies on the use of clay, clay minerals and charcoal to adsorb bovine rotavirus and bovine coronavirus. Veterinary Microbiology, 63(24):137-146. doi: 10.1016/S0378 1135(98)00241-7.

29. Conte, P., V. Marsala, C. De Pasquale, S. Bubici, M. Valagussa, A. Pozzi \& G. Alonzo, 2013 Nature of water-biochar interface interactions. GCB Bioenergy, 5(2):116-121. doi: $10.1111 /$ gcbb.12009.

30. Cooney, D.O. \& M. Roach, 1979. Sucrose as a sweetener for activated charcoal. American Journal of Hospital Pharmacy, 36(6):797798. doi: 10.1093/ajhp/36.6.797.

31. Crome, P., S. Dawling, R.A. Braithwaite, J. Masters \& R. Walke, 1977. Effect of activated charcoal on absorption of nortriptyline. Lancet, 310(8050):1203-1205. doi: 10.1016/ S0140-6736(77)90440-8.

32. Dakoviæ, A., M. Tomaševiæ-Èanoviæ, V. Dondur, G.E. Rottinghaus, V. Medakoviæ, \& S. Zariæ, 2005. Adsorption of mycotoxins by organozeolites. Colloids Surfaces B biointerfaces, 46 (1), pp. 20-25.

33. Dalvi, R.R. \& C. McGowan, 1984. Experimental induction of chronic aflatoxicosis in chickens by purified aflatoxin $\mathrm{B} 1$ and its reversal by activated charcoal, phenobarbital, and reduced glutathione. Poultry Science, 63(3):485-491. doi: 10.3382/ps.0630485.

34. Decker, W.J. \& D.G. Corby, 1971. Activated charcoal as a gastrointestinal decontaminant. Experiences with experimental animals and human subjects. Bulletin of Environmental Contamination and Toxicology, 6(2):189192. doi: 10.1007/BF01540104.

35. Demirbas, A., 2017. Utilization of date biomass waste and date seed as bio-fuels source. Energy Sources, Part A: Recovery, Utilization, and Environmental Effects. 39(8): 754-760.

36. Derlet, R.W. \& T.E. Albertson, 1986. Activated charcoal-Past, present and future. Western 
Journal of Medicine, 145(4):492-496.

37. Deutzmann, J.S., P. Stief, J. Brandes \& B.B, Schink, 2014. Anaerobic methane oxidation coupled to denitrification is the dominant methane sink in a deep lake. Proceedings of the National Academy of Sciences of the United States of America, 111(51):1827318278. doi: 10.1073/pnas.1411617111.

38. Devenas, K., S. Neto, D. Oliveira \& M. Gonçalves, 2018. Characterization of Biochar from Green Coconut Shell and Orange Peel Wastes. Revista Virtual de Química, 10: 288294. 10.21577/1984-6835.20180022.

39. Di Natale, F., M. Gallo \& R. Nigro, 2009. Adsorbents selection for aflatoxins removal in bovine milks. Journal of Food Engineering, 95(1):186-191. doi: 10.1016/ j.jfoodeng.2009.04.023.

40. Diaz, D.E., W.M. Hagler Jr., B.A. Hopkins, L.W. Whitlow, 2002. Aflatoxin binders I: in vitro binding assay for aflatoxin B1 by several potential sequestering agents. Mycopathologia, 156(3):223-226. doi: 10.1023/A:1023388321713.

41. Diaz, D.E., 2004. Aflatoxin binders II: Reduction of aflatoxin M1 in milk by sequestering agents of cows consuming aflatoxin in feed," Mycopathologia, 157 (2), pp. 233-241.

42. Diez-Gonzalez, F., T.R. Callaway, M.G. Kizoulis \& J.B. Russel, 1998. Grain feeding and the dissemination of acid-resistant Escherichia coli from cattle. Science, 281(5383):16661668. doi: 10.1126/science.281.5383.1666.

43. Dobson, R.C., J.E. Fahey, D.L. Ballee \& E.R. Baugh, 1971. Reduction of chlorinated hydrocarbon residue in swine. Bulletin of Environmental Contamination and Toxicology, 6(2):189-192. doi:

44. Downie, A., A. Crosky \& P. Monroe, 2009. Biochar for environmental management: science and technology. Earthscan, London, pp. 13-32.

45. Dunnigan, L., J. Ashmana, J., X. Zhang \& C. Waikwong, 2018. Production of biochar from rice husk: Particulate emissions from the combustion of raw pyrolysis volatiles. Journal of Cleaner Production. 172(20): 1639-1645.

46. Edrington, T., L. Kubena, R. Harvey \& G. Rottinghaus, 1997. Influence of a superactivated charcoal on the toxic effects of aflatoxin or T-2 toxin in growing broilers. Poultry Science, 76(9):1205-1211. doi: $10.1093 / \mathrm{ps} / 76.9 .1205$.

47. El Hanandeh, A., 2013. Carbon abatement via treating the solid waste from the Australian olive industry in mobile pyrolysis units: LCA with uncertainty analysis. Waste Management \& Research. 31(4): 341-352.

48. Erb, F., D. Gairin \& N. Leroux, 1989. Activated charcoals: properties-experimental studies. Journal de Toxicologie Clinique et Expérimentale, 9:235-248.

49. Erickson, P.S., N.L. Whitehouse \& M.L. Dunn, 2011. Activated carbon supplementation of dairy cow diets: effects on apparent totaltract nutrient digestibility and taste preference. Professional Animal Scientist, 27(5):428-434. doi: 10.15232/ S1080-7446(15)30515-5.

50. European Biochar Foundation (EBC), 2012. European biochar certificate-guidelines for a sustainable production of biochar. http:// www.european-biochar.org/en/download. [12 January 2016]. http://www.europeanbiochar.org/en/download

51. European Biochar Foundation (EBC), 2012. European biochar certificate-guidelines for a sustainable production of biochar. http:// www.european-biochar.org/en/download. [12 January 2016]. http://www.europeanbiochar.org/en/download

52. European Biochar Foundation (EBC), 2018. Guidelines for EBC-feed certification. http:/ /www.european-biochar.org/biochar/media/ doc/ebc-feed.pdf. [4 January 2019]. http:// www.european-biochar.org/biochar/media/ doc/ebc-feed.pdf

53. European Biochar Foundation (EBC), 2018. Guidelines for EBC-feed certification. http:/ 
/www.european-biochar.org/biochar/media/ doc/ebc-feed.pdf. [4 January 2019]. http:// www.european-biochar.org/biochar/media/ doc/ebc-feed.pdf.

54. Fujita, H., K. Honda, R. Iwakiri, K.S. Guruge, N. Yamanaka \& N. Tanimura, 2012. Suppressive effect of polychlorinated dibenzo-p-dioxins, polychlorinated dibenzofurans and dioxin-like polychlorinated biphenyls transfer from feed to eggs of laying hens by activated carbon as feed additive. Chemosphere, 88(7):820-827. doi: 10.1016/j.chemosphere.2012.03.088. [PubMed] [CrossRef] [Google Scholar].

55. Galvano, F., 1996. Activated carbons: in vitro affinity for aflatoxin B1 and relation of adsorption ability to physicochemical parameters. J. Food Prot., 59 (5), pp. 545550.

56. Galvano, F., A. Piva, A. Ritieni \& G. Galvano, 2001. Dietary strategies to counteract the effects of mycotoxins: a review. J. Food Prot., 64 (1), pp. 120-131.

57. Gaudreault, P., P.A. Friedman \& F.H. Lovejoy Jr., 1985. Efficacy of activated charcoal and magnesium citrate in the treatment of oral paraquat intoxication. Annals of Emergency Medicine, 14(2):123-125. doi: 10.1016/ S0196-0644(85)81072-6.

58. Gerlach, A. \& H.P. Schmidt, 2012. Pflanzenkohle in der Rinderhaltung. Ithaka Journal, 1:8084.

59. Gerlach, A. \& H.P. Schmidt, 2014. The use of biochar in cattle farming, the Biochar Journal, Arbaz, Switzerland. ISSN 2297-1114 www.biochar-journal.org/en/ct/9 Version of 01 th August 2014.

60. Gerlach, H., A. Gerlach, W. Schrödl, B. Schottdorf, S. Haufe, H. Helm, A. Shehata \& M. Krüger, 2014. Oral application of charcoal and humic acids to dairy cows influences Clostridium botulinum blood serum antibody level and glyphosate excretion in urine. Journal of Clinical Toxicology, 4(2):186. doi: 10.4172/21610495.1000186.
61. Gerlach, H., A. Gerlach, W. Schrödl, B. Schottdorf \& S. Haufe, 2014. Oral Application of Charcoal and Humic acids to Dairy Cows Influences Clostridium botulinum Blood Serum Antibody Level and Glyphosate Excretion in Urine. J Clin Toxicol 4:186. doi: 10.4172/2161-0495.1000186

62. Ghouma, I., M. Jeguirim., C. Guizani, A. Ouederni \& L. Limousy, 2017. Pyrolysis of Olive Pomace: Degradation Kinetics, Gaseous Analysis and Char Characterization. Waste and Biomass Valorization. 10.1007/ s12649-017-9919-8.

63. Godlewska, P., H.P. Schmidt, Y.S. Ok \& P. Oleszczuk, 2017. Biochar for composting improvement and contaminants reduction. A review. Bioresource Technology, 246:193202. doi: 10.1016/j.biortech.2017.07.095.

64. Guo, M., S.M. Uchimiya \& Z. He, 2016. Agricultural and environmental applications of biochar: Advances and barriers, no. sssaspecpub63. Soil Science Society of America, Inc.

65. Gurtler, J.B., A.A. Boateng, Y.H. Han \& D.D. Douds Jr., 2014. Inactivation of E. coli O157: $\mathrm{H} 7$ in cultivable soil by fast and slow pyrolysis-generated biochar. Foodborne Pathogens and Disease, 11(3):215-223. doi: 10.1089/fpd.2013.1631.

66. Hagemann, N., K. Spokas, H.P. Schmidt, R. Kägi, M.A. Böhler \& T. Bucheli, 2018. Activated carbon, biochar and charcoal: linkages and synergies across pyrogenic carbon's ABCs. Water, 10(2):182. doi: 10.3390/w10020182.

67. Hall, K.E., K.A. Spokas, B. Gamiz, L. Cox, S.L. Papiernik \& W.C. Koskinen, 2018. Glyphosate sorption/desorption on biochars-interactions of physical and chemical processes. Pest Management Science, 74(5):1206-1212. doi: 10.1002/ ps. 4530 .

68. Hansen, H.H., I.M.L.D. Storm \& A.M. Sell, 2012. Effect of biochar on in vitro rumen methane production. Acta Agriculturae Scandinavica, Section A-Animal Science, 
62(4):305-309. doi: $10.1080 /$ 09064702.2013 .789548 .

69. Hatch, R.C., J.D. Clark, A.V. Jain \& R. Weiss, 1982. Induced acute aflatoxicosis in goats: treatment with activated charcoal or dual combinations of oxytetracycline, stanozol, and activated charcoal [Aflatoxins, Aspergillus flavus]. Am. J. Vet. Res.

70. Herath, I., P. Kumarathilaka, M.I. Al-Wabel, A. Abduljabbar, M. Ahmad, A.R.A. Usman \& M. Vithanage, 2016. Mechanistic modeling of glyphosate interaction with rice husk derived engineered biochar. Microporous and Mesoporous Materials, 225:280-288. doi: 10.1016/j.micromeso.2016.01.017.

71. Hristov, A.N., J. Oh, C. Lee, R. Meinen, F. Montes, T. Ott, J. Firkins, A. Rotz, C. Dell, A. Adesogan, W. Yang, J. Tricarico, E. Kebreab, G. Waghorn \& J. Dijkstra, 2013. Oosting S. Mitigation of greenhouse gas emissions in livestock production. A review of technical options for non-CO2 emissions. In: Gerber PJ, Henderson B, Makkar H, editors. Mitigation of Greenhouse Gas Emissions in Livestock Production-A Review of Technical Options for NonCO2 Emissions. Rome: FAO, pp. 9-63.

72. Humphreys, F.R. \& G.E. Ironside, 1980. Charcoal from New South Wales. Sidney: Forestry Commission of New South Wales.

73. Huwig, A., S. Freimund, O. Käppeli \& H. Dutler, 2001. Mycotoxin detoxication of animal feed by different adsorbents. Toxicol. Lett., 122 (2), pp. 179-188.

74. International Biochar Initiative (IBI), 2015. Standardized product definition and product testing guidelines for biochar that is used in soil. Version 1.1https:// www.biocharinternational.org/wp-content/ uploads/2018/04/Technical-Note_StandardsV1.1.pdf 2015.

75. Islam, M.M., S.T. Ahmed, Y.J. Kim, H.S. Mun, Y.J. Kim \& C.J. Yang, 2014. Effect of sea tangle (Laminaria japonica) and charcoal supplementation as alternatives to antibiotics on growth performance and meat quality of ducks. Asian-Australasian Journal of Animal Sciences, 27(2):217-224. doi: 10.5713/ ajas.2013.13314. [PMC free article] [PubMed] [CrossRef] [Google Scholar.

76. Iwakiri, R., R. Asano \& K. Honda, 2007. Effects of carbonaceous adsorbent on accumulation and excretion of dioxins in rat. Organohalogen Compound, 69:2391-2394.

77. Jacoby, M., 1919. Einführung in die experimentelle Therapie. Berlin: Julius Springer.

78. Jeffery, S., F.G.A. Verheijen, C. Kammann \& D. Abalos, 2016. Biochar effects on methane emissions from soils: a meta-analysis. Soil Biology and Biochemistry, 101:251-258. doi: 10.1016/j.soilbio.2016.07.021.

79. Jeffery, S., D. Abalos, M. Prodana, A.C. Bastos, J.W. Van Groenigen, B.A. Hungate \& F. Verheijen, 2017. Biochar boosts tropical but not temperate crop yields. Environmental Research Letters, 12(5):053001. doi: 10.1088/1748-9326/aa67bd.

80. Johnson, K.A. \& D.E. Johnson, 1995. Methane emissions from cattle. Journal of Animal Science, 73(8):2483-2492. doi: 10.2527/ 1995.7382483x.

81. Joseph, S., O. Husson, E. Graber, L. Van Zwieten, S. Taherymoosavi, T. Thomas, S. Nielsen, J. Ye, G. Pan, C. Chia, P. Munroe, J. Allen, Y. Lin, X. Fan \& S. Donne, 2015a. The electrochemical properties of biochars and how they affect soil redox properties and processes. Agronomy, 5(3):322-340. doi: 10.3390/agronomy5030322.

82. Joseph, S., O. Husson, E. Graber, L. Van Zwieten, S. Taherymoosavi, T. Thomas, S. Nielsen, J. Ye, G. Pan, C. Chia, P. Munroe, J. Allen, Y. Lin, X. Fan \& S. Donne, 2015a. The electrochemical properties of biochars and how they affect soil redox properties and processes. Agronomy, 5(3):322-340. doi: 10.3390/agronomy5030322.

83. Chan, K. \& Z. Xu, 2009. Biochar: Nutrient Properties and Their Enhancement. In Biochar for Environmental Management: Science and Technology (Eds J Lehmann and 
S Joseph), Earthscan: London, UK, 53-66.

84. Kamimura, H., N. Koga, K. Oguri, H. Yoshimura, Y. Honda \& M. Nakano, 2009. Enhanced faecal excretion of 2,3,4,7,8pentachlorodibenzofuran in rats by a longterm treatment with activated charcoal beads. Xenobiotica, 18(5):585-592. doi: 10.3109/00498258809041695. [PubMed]

85. Kammann, C.I., H.P. Schmidt, N. Messerschmidt, S. Linsel, D. Steffens, C. Müller, H.W. Koyro, P. Conte \& S. Joseph, 2015. Erratum: plant growth improvement mediated by nitrate capture in co-composted biochar. Scientific Reports, 5(1):12378. doi: 10.1038/srep12378.

86. Kammann, C.I., H.P. Schmidt, N. Messerschmidt, S. Linsel, D. Steffens, C. Müller, H.W. Koyro, P. Conte \& S. Joseph, 2015. Erratum: plant growth improvement mediated by nitrate capture in co-composted biochar. Scientific Reports, 5(1):12378. doi: 10.1038/srep12378.

87. Kammann, C., J. Ippolito, N. Hagemann, N. Borchard, M.L. Cayuela, J.M. Estavillo, T. Fuertes-Mendizabal, S. Jeffery, J. Kern, J. Novak, D. Rasse, S. Saarnio, H.P. Schmidt, K. Spokas \& N. Wrage-Mönnig, 2017. Biochar as a tool to reduce the agricultural greenhouse-gas burden-knowns, unknowns and future research needs. Journal of Environmental Engineering and Landscape Management, 25(2):114-139. doi: 10.3846/ 16486897.2017.1319375.

88. Kana, J.R., A. Teguia, B.M. Mungfu \& J. Tchoumboue, 2010. Growth performance and carcass characteristics of broiler chickens fed diets supplemented with graded levels of charcoal from maize cob or seed of Canarium schweinfurthii Engl. Tropical Animal Health and Production, 43(1):51-56. doi: 10.1007/ s11250-010-9653-8. [PubMed] [CrossRef] [Google Scholar]

89. Kana, J.R., A. Teguia, B.M. Mungfu \& J. Tchoumboue, 2011. Growth performance and carcass characteristics of broiler chickens fed diets supplemented with graded levels of charcoal from maize cob or seed of Canarium schweinfurthii Engl. Tropical Animal Health and Production, 43(1):51-56. doi: 10.1007/ s11250-010-9653-8. [PubMed] [CrossRef] [Google Scholar]

90. Kana, J.R., A. Teguia \& A. Fomekong, 2012. Effect of substituting soybean meal with cowpea (Vigna unguiculata WAL) supplemented with natural plant charcoals in broiler diet on growth performances and carcass characteristics. Iranian Journal of Applied Animal Science, 2:377-381. [Google Scholar]

91. Kappler, A., M.L. Wuestner, A. Ruecker, J. Harter, M. Halama \& S. Behrens, 2014. Biochar as an electron shuttle between bacteria and Fe(III) minerals. Environmental Science \& Technology Letters, 1(8):339-344. doi: 10.1021/ez5002209.

92. Kastening, B., M. Hahn, B. Rabanus, M. Heins \& U. Zum Felde, 1997. Electronic properties and double layer of activated carbon. Electrochimica Acta, 42(18):2789-2799. doi: 10.1016/S0013-4686(97)00082-0.

93. Keller, L.A.M., C.M. Pereyra, L.R. Cavaglieri, A.M. Dalcero \& C.A.R. Rosa, 2012. Fungi and mycotoxins from pre-and poststorage brewer's grain intended for bovine intensive rearing. ISRN Vet. Sci.

94. Kim, B.K. \& Y.J. Kim, 2005. Effects of feeding charcoal powder and vitamin A on growth performance, serum profile and carcass characteristics of fattening Hanwoo steers. Journal of Animal Science and Technology, 47(2):233-242. doi: 10.5187/ JAST.2005.47.2.233. [CrossRef]

95. Kim, K.E., S.J. You, B.K. Ahn, T.S. Jo, B.J. Ahn, D.H. Choi \& C.W. Kang, 2006. Effects of dietary activated charcoal mixed with wood vinegar on quality and chemical composition of egg in laying hens. Journal of Animal Science and Technology, 48(1):5968. doi: 10.5187/jast.2006.48.1.059. [CrossRef].

96. Kim, K.E., S.J. You, B.K. Ahn, T.S. Jo, B.J. Ahn, D.H. Choi \& C.W. Kang, 2006. Effects 
of dietary activated charcoal mixed with wood vinegar on quality and chemical composition of egg in laying hens. Journal of Animal Science and Technology, 48(1):5968. doi: 10.5187/jast.2006.48.1.059.

97. Kim, S.H., I.C. Lee, S.S. Kang, C.J. Moon, S.H. Kim, D.H. Shin, H.C. Kim, J.C. Yoo \& J.C. Kim, 2011. Effects of bamboo charcoal and bamboo leaf supplementation on performance and meat quality in chickens. Journal of Life Science. 21(6):805-810. doi: 10.5352/ JLS.2011.21.6.805.

98. Kim, K.S., Y.H. Kim, J.C. Park, W. Yun, K.I. Jang, D.I. Yoo, D.H. Lee, B.G. Kim \& J.H. Cho, 2017. Effect of organic medicinal charcoal supplementation in finishing pig diets. Korean Journal of Agricultural Science, 44:50-59. [Google Scholar].

99. Kitzler, H., C. Pfeifer \& H. Hofbauer, 2012. Combustion of reeds in a $3 \mathrm{MW}$ district heating plant. Int. J. Environ. Sci. Dev., 3: 407-411.

100. Kloss, S., F. Zehetner, A. Dellantonio, R. Hamid, F. Ottner, V. Liedtkeand \& G. Soja, 2012. Characterization of slow pyrolysis biochars: effects of feedstocks and pyrolysis temperature on biochar properties. J Environ Qual. 41(4): 990-1000. doi: 10.2134/ jeq2011.0070.

101. Kluepfel, L, M. Keiluweit, M. Kleber \& M. Sander, 2014. Redox properties of plant biomass-derived black carbon (biochar) Environmental Science \& Technology, 48(10):5601-5611. doi: 10.1021/es500906d.

102. Knutson, H.J., M.A. Carr, L.A. Branham, C.B. Scott \& T.R. Callaway, 2006. Effects of activated charcoal on binding E. coli O157: H7 and Salmonella typhimurium in sheep. Small Ruminant Research, 65(12):101-105. doi: 10.1016/ j.smallrumres.2005.05.019. [CrossRef] [Google Scholar].

103. Komulainen, M.P., E. Simi, I. Hagelberg, S. Ikonen \& S. Lyytinen, 2008. Possibilities of Using the Common Reed for Energy
Generation in Southern Finland; Turku University of Applied Sciences: Turku, Finland, pp. 21.

104. Konsolakis, M., N. Kaklidis, G.E. Marnellos, D. Zaharaki \& K. Komnitsas, 2015. Assessment of biochar as feedstock in a direct carbon solid oxide fuel cell. RSC Advances, 5(90):73399-73409. doi: 10.1039/ C5RA13409A.

105. Kubena, L.F., R.B. Harvey, T.D. Phillips, D.E. Corrier \& W.E. Huff, 1990. Diminution of aflatoxicosis in growing chickens by the dietary addition of a hydrated, sodium calcium aluminosilicate. Poultry Science, 69(5):727-735. doi: 10.3382/ps.0690727.

106. Kutlu, H.R., 1998. Effects of dietary wood charcoal on performance and fatness of broiler chicks. Br. Poult. Sci., 39 (S1), pp. 31-32.

107. Kutlu, H.R., I. Ünsal \& M. Görgülü, 2001. Effects of providing dietary wood (oak) charcoal to broiler chicks and laying hens. Anim. Feed Sci. Technol., 90 (3-4), pp. 213 226.

108. Lee, J.J., S.H. Park, D.S. Jung, Y.I. Choi \& J.S. Choi, 2011. Meat quality and storage characteristics of finishing pigs by feeding stevia and charcoal. Korean Journal for Food Science of Animal Resources, 31(2):296-303. doi: 10.5851/kosfa.2011.31.2.296.

109. Lehmann, J.D., S. Joseph \& I. Ebrary, 2009. Biochar for environmental management: Science and technology. Sterling, VA; London: Earthscan.

110. Lehmann, J., 2007. A handful of carbon. Nature., 447(7141): 143.

111. Leng, R.A., T.R. Preston \& S. Inthapanya, 2012: Biochar reduces enteric methane and improves growth and feed conversion in local "Yellow" cattle fed cassava root chips and fresh cassava foliage. Livestock Research for Rural Development. Volume 24, Article \#199. Retrieved May 24, 2017, from http:// www.lrrd.org/lrrd24/11/leng24199.htm.

112. Leng, R.A., S. Inthapanya \& T.R. Preston, 2013. 
All biochars are not equal in lowering methane production in in vitro rumen incubations. Livestock Research for Rural Development, 25:106.

113. Leng, R.A., T.R. Preston \& S. Inthapanya, 2013. Biochar reduces enteric methane and improves growth and feed conversion in local "Yellow" cattle fed cassava root chips and fresh cassava foliage. Livestock Research for Rural Development, 24:Article \#199.

114. Liu, F., A.E. Rotaru, P.M. Shrestha, N.S. Malvankar, K.P. Nevin \& D.R. Lovley, 2012. Promoting direct interspecies electron transfer with activated carbon. Energy \& Environmental Science, 5(10):8982. doi: 10.1039/c2ee22459c.

115. Liu, Q., Y. Zhang, B. Liu, J.E. Amonette, Z. Lin, G. Liu, P. Ambus \& Z. Xie, 2018. How does biochar influence soil $\mathrm{N}$ cycle? A metaanalysis. Plant and Soil, 426(1-2):211-225. doi: $10.1007 / \mathrm{s} 11104-018-3619-4$.

116. Liu, Q., Y. Zhang, B. Liu, J.E. Amonette, Z. Lin, G. Liu, P. Ambus \& Z. Xie, 2018. How does biochar influence soil $\mathrm{N}$ cycle? A metaanalysis. Plant and Soil, 426(1-2):211-225. doi: 10.1007/s11104-018-3619-4.

117. Majewska, T. \& K. Pudyszak, 2011. The effect of charcoal addition to diets for broilers on performance and carcass parameters. Veterinarija ir Zootechnika (Vet Med Zoot), 55:10-12. [Google Scholar].

118. Majewska, T., D. Mikulski \& T. Siwik, 2009. Silica grit, charcoal and hardwood ash in turkey nutrition. Journal of Elementology, 14(3):489-500. doi: 10.5601/ jelem.2009.14.3.07. [CrossRef] [Google Scholar]

119. Majewska, T., D. Pyrek \& A. Faruga, 2002. A note on the effect of charcoal supplementation on the performance of Big 6 heavy tom turkeys. Journal of Animal and Feed Science, 11(1):135-141. doi: 10.22358/ jafs/67797/2002. [CrossRef] [Google Scholar].

120. Mandal, K.G., A.K. Misra, K.M. Hati, K.K.
Bandyopadhyay \& P.K. Ghosh, 2004. Rice residue management options and effects on soil properties and crop productivity. Journal of Food Agriculture and Environment. 2: 224-231.

121. Mandal, A., N. Singh \& T.J. Purakayastha, 2017. Characterization of pesticide sorption behaviour of slow pyrolysis biochars as lowcost adsorbent for atrazine and imidacloprid removal. Science of the Total Environment, 577:376-385. doi: 10.1016/ j.scitotenv.2016.10.204.

122. McHenry, M.P., 2010. Carbon-based stock feed additives: a research methodology that explores ecologically delivered $\mathrm{C}$ biosequestration, alongside live weights, feed use efficiency, soil nutrient retention, and perennial fodder plantations. Journal of the Science of Food and Agriculture, 90(2):183187. doi: $10.1002 /$ jsfa.3818.

123. McKenzie, R.A., 1991. Bentonite as therapy for Lantana camara poisoning of cattle. Australian Veterinary Journal, 68(4):146-148. doi: $10.1111 / \mathrm{j} .1751$ 0813.1991.tb03159.x.

124. McLennan, M.W. \& M.L. Amos, 1989. Treatment of lantana poisoning in cattle. Australian Veterinary Journal, 66(3):93-94. doi: 10.1111/j.17510813.1989.tb09754.x.

125. McLennan, M.W. \& M.L. Amos, 1989. Treatment of lantana poisoning in cattle. Australian Veterinary Journal, 66(3):93-94. doi: 10.1111/j.17510813.1989.tb09754.x.

126. Mekbungwan, A., K. Yamauchi, T. Sakaida \& T. Buwjoom, 2008. Effects of a charcoal powder-wood vinegar compound solution in piglets for raw pigeon pea seed meal. Animal, 2(3):366-374. doi: 10.1017/ S1751731107001243.

127. Mézes, M., K. Balogh \& K. Tóth, 2010. Preventive and therapeutic methods against the toxic effects of mycotoxins-a review. Acta veterinaria Hungarica, 58(1):117. doi: 10.1556/AVet.58.2010.1.1. 
128. Misihairabgwi, J.M., C.N. Ezekiel, M. Sulyok, G.S. Shephard \& R. Krska, 2017. Mycotoxin contamination of foods in Southern Africa: A 10-year review (2007-2016). Crit. Rev. Food Sci. Nutr., pp. 1-16.

129. Murray, R.M., A.M. Bryant \& R.A. Leng, 1976. Rates of production of methane in the rumen and large intestine of sheep. British Journal of Nutrition, 36(1):1-14. doi: 10.1079/ BJN19760053. Leng, R.A., Preston, T.R., Inthapanya, S., 2012. Biochar reduces enteric methane and improves growth and feed conversion in local 'Yellow' cattle fed cassava root chips and fresh cassava foliage. Livest. Res. Rural Dev., 24 (11).

130. Myrhe, G.D., F.M. Chindell, W. Bréon, J. Collins, J. Fuglestvedt, D. Huang, J.F. Koch, D. Lamarque, B. Lee, T. Mendoza, A. Nakajima, G. Robick, T. Stephens, T. Takemura \& H. Zhang, 2013. Anthropogenic and natural radiative forcing. In: Stocker TF, Qin D, Plattner G-K, Tignor M, Allen SK, Boschung J, Nauels A, Xia Y, Bex V, Midgley PM, editors. Climate Change 2013: The Physical Science Basis. Contribution of Working Group I to the Fifth Assessment Report of the Intergovernmental Panel on Climate Change. Cambridge; New York: Intergovernmental Panel on Climate Change (IPCC).

131. Naeem, M.A., M. Khalid, M. Aon, G.A.M. Tahir, G.A.M. Amjad, A. Yand \& S.S. Akthar, 2017. Effect of wheat and rice straw biochar produced at different temperatures on maize growth and nutrient dynamics of a calcareous soil. Journal of Archives of Agronomy and Soil Science. 2048-2061.

132. Naka, K., S. Watarai, Tana, K. Inoue, Y. Kodama, K. Oguma, T. Yasuda \& H. Kodama, 2001. Adsorption effect of activated charcoal on enterohemorrhagic Escherichia coli. Journal of Veterinary Medical Science, 63(3):281285. doi: 10.1292/jvms.63.281. [PubMed] [CrossRef] [Google Scholar]

133. Nasser, R.A., 2014. An evaluation of the use of midribs from common date palm cultivars grown in Saudi Arabia for energy production.
BioResource. 9: 4343-4357.

134. Naumann, H.D., J.P. Muir, B.D. Lambert, L.O. Tedeschi \& M.M. Kothmann, 2013. Condensed tannins in the ruminant environment: a perspective on biological activity. Journal of Agricultural Sciences, $1: 8-20$.

135. Neuvonen, P.J. \& K.T. Olkkola, 1988. Oral activated charcoal in the treatment of intoxications. Medical Toxicology and Adverse Drug Experience, 3(1):33-58. doi: 10.1007/BF03259930.

136. Neuvonen, P.J. \& K.T. Olkkola, 1988. Oral activated charcoal in the treatment of intoxications. Medical Toxicology and Adverse Drug Experience, 3(1):33-58. doi: 10.1007/BF03259930.

137. Nevin, K.P., T.L. Woodard, A.E. Franks, Z.M. Summers \& D.R. Lovley, 2010. Microbial electrosynthesis: feeding microbes electricity to convert carbon dioxide and water to multicarbon extracellular organic compounds. mBio, 1(2):e00103-10. doi: 10.1128/mBio.00103-10.

138. O’Toole, A., D. Andersson, A. Gerlach, B. Glaser, C.I. Kammann, J. Kern, K. Kuoppamäki, J. Mumme, M. Schmidt HansPeter Schulze, M. Srocke Franziska Stenrød \& J. Stenström, 2016. Current and future applications for biochar. In: Shackley S, Ruysschaert G, Zwart K, Glaser B, editors. Biochar in European Soils and Agriculture: Science and Practice. Abington: Taylor \& Francis Group, pp. 253-280.

139. O'Toole, A., D. Andersson, A. Gerlach, B. Glaser, C.I. Kammann, J. Kern, K. Kuoppamäki, J. Mumme, M. Schmidt HansPeter Schulze, M. Srocke Franziska Stenrød \& J. Stenström, 2016. Current and future applications for biochar. In: Shackley S, Ruysschaert G, Zwart K, Glaser B, editors. Biochar in European Soils and Agriculture: Science and Practice. Abington: Taylor \& Francis Group, pp. 253-280.

140. Okonek, S., H. Setyadharma, A. Borchert \& E.G. Krienke, 1982. Activated charcoal is as 
effective as fuller's earth or bentonite in paraquat poisoning. Klinische Wochenschrift, 60(4):207-210. doi: 10.1007/BF01715588. [PubMed] [CrossRef] [Google Scholar]

141. Olkkola, K.T. \& P.J. Neuvonen, 1989. Treatment of intoxications using single and repeated doses of oral activated charcoal. Journal de toxicologie clinique et expérimentale, 9:265275.

142. Pandey, G. \& S. Madhuri, 2014. Heavy metals causing toxicity in animals and fishes. Res. J. Anim. Vet. Fish. Sci., 2 (2), pp. 17-23.

143. Paraud, C., I. Pors, J.P. Journal, P. Besnier, I. Reisdorffer \& C. Chartier, 2011. Control of cryptosporidiosis in neonatal goat kids: efficacy of a product containing activated charcoal and wood vinegar liquid (Obionekk®) in field conditions. Veterinary Parasitology, 180(3-4):354-357. doi: 10.1016/j.vetpar.2011.03.022.

144. Pennsylvania State College, 1905. Annual report of the Pennsylvania agricultural experiment station. Pennsylvania: Pennsylvania State College.

145. Pesevski, M.D.K., 2010. Possibilities for utilization of tobacco stems for production of energetic briquettes. J. Agric. Sci. 55: 4554.

146. Phanthavong, V., N. Viengsakoun, I. Sangkhom \& T.R. Preston, 2015. Effect of biochar and leaves from sweet or bitter cassava on gas and methane production in an in vitro rumen incubation using cassava root pulp as source of energy. Livestock Research for Rural Development, 27:Article \#72.

147. Phongpanith, S., S. Inthapanya \& T.R. Preston, 2013. Effect on feed intake, digestibility and $\mathrm{N}$ balance in goats of supplementing a basal diet of Muntingia foliage with biochar and water spinach (Ipomoea aquatica). Livest. Res. Rural Dev. 25 (35).

148. Phongphanith, S. \& T.R. Preston, 2018. Effect of rice-wine distillers' byproduct and biochar on growth performance and methane emissions in local "Yellow" cattle fed ensiled cassava root, urea, cassava foliage and rice straw. Livestock Research for Rural Development, 28:Article \#178.

149. Pituya, P., T. Sriburi \& S. Wijitkosum, 2016. Properties of Biochar Prepared from Acacia Wood and Coconut Shell for Soil Amendment. Environ Sci Pollut Res Int. 25(2):1147-1156. doi: 10.1007/s11356-0170495-z. Epub 2017 Oct 27.

150. Prasai, T.P., K.B. Walsh, S.P. Bhattarai, D.J. Midmore, T.T.H. Van, R.J. Moore \& D. Stanley, 2016. Biochar, bentonite and zeolite supplemented feeding of layer chickens alters intestinal microbiota and reduces campylobacter load. PLOS ONE, 11(4):e0154061. doi: 10.1371/ journal.pone.0154061.

151. Rao, S.B.N., R.C. Chopra \& V. Radhika, 2004. Sodium bentonite or activated charcoal supplementation on dry matter intake and growth rate of young goats fed diets with aflatoxin B1. Indian J. Anim. Sci.

152. Richter, H., K.P. Nevin, H. Jia, D.A. Lowy, D.R. Lovley \& L.M. Tender, 2009. Cyclic voltammetry of biofilms of wild type and mutant Geobacter sulfurreducens on fuel cell anodes indicates possible roles of $\mathrm{OmcB}$, OmcZ, type IV pili, and protons in extracellular electron transfer. Energy \& Environmental Science, 2(5):506. doi: $10.1039 / \mathrm{b} 816647 \mathrm{a}$.

153. Rogosic, J., J.A. Pfister, F.D. Provenza \& D. Grbesa, 2006. The effect of activated charcoal and number of species offered on intake of Mediterranean shrubs by sheep and goats. Appl. Anim. Behav. Sci., 101 (3-4), pp. 305317.

154. Ruttanavut, J., K. Yamauchi, H. Goto \& T. Erikawa, 2009. Effects of dietary bamboo charcoal powder including vinegar liquid on growth performance and histological intestinal change in Aigamo ducks. International Journal of Poultry Science, 8(3):229-236. doi: 10.3923/ ijps.2009.229.236.

155. Ruttanawut, J., 2014. Effects of dietary bamboo charcoal powder including bamboo vinegar 
liquid supplementation on growth performance, fecal microflora population and intestinal morphology in betong chickens. Japan Poultry Science Association., 51:165171. doi: 10.2141/jpsa.0130109.

156. Safaei Khorram, M., Q. Zhang, D. Lin, Y. Zheng, H. Fang \& Y. Yu, 2016. Biochar: a review of its impact on pesticide behavior in soil environments and its potential applications. Journal of Environmental Sciences, 44:269279. doi: 10.1016/j.jes.2015.12.027. [

157. Saleem, A.M., G.O. Ribeiro, W.Z. Yang, T. Ran, K.A. Beauchemin, E.J. McGeough, K.H. Ominski, E.K. Okine \& T.A. McAllister, 2018. Effect of engineered biocarbon on rumen fermentation, microbial protein synthesis, and methane production in an artificial rumen (RUSITEC) fed a high forage diet1. Journal of Animal Science, 96(Suppl_3):3121-3130. doi: 10.1093/jas/ sky404.865.

158. Saleem, A.M., G.O. Ribeiro, W.Z. Yang, T. Ran, K.A. Beauchemin, E.J. McGeough, K.H. Ominski, E.K. Okine \& T.A. McAllister, 2018. Effect of engineered biocarbon on rumen fermentation, microbial protein synthesis, and methane production in an artificial rumen (RUSITEC) fed a high forage diet1. Journal of Animal Science, 96(Suppl_3):3121-3130. doi: 10.1093/jas/ sky404.865. [PMC free article] [PubMed

159. Saleh, F., R. Samsuddin \& M. Husin, 2014. Biofuel source from combination feed of sewage and rice waste. In: International Conference on Environment Science Engineering IPCBEE; IACSIT Press: Singapore, 8: 6872.

160. Samanya, M. \& K. Yamauchim, 2001. Morphological changes of the intestinal villi in chickens fed the dietary charcoal powder including wood vinegar compounds. Journal of Poultry Science, 38(4):289-301. doi: 10.2141/jpsa.38.289.

161. Saquing, J.M., Y.H. Yu \& P.C. Chiu, 2016. Wood-derived black carbon (biochar) as a microbial electron donor and acceptor.
Environmental Science \& Technology Letters, 3(2):62-66. doi: 10.1021/ acs.estlett.5b00354.

162. Savage, E.S., 1917. Feeding dairy cattle. Holstein-Friesian World, 1:47.

163. Schirrmann, U., 1984. Aktivkohle und ihre Wirkung auf Bakterien und deren Toxine im Gastrointestinaltrakt. Munich: TU München. [Google Scholar].

164. Schmidt, H.P. \& S. Shackley, 2016. Biochar horizon 2025. In: Shackley S, Ruysschaert G, Zwart K, Glaser B, editors. Biochar in European Soils and Agriculture: Science. Abingdon: Taylor \& Francis Group, pp. 281-289. [Google Scholar]

165. Schmidt, H.P. \& S. Shackley, 2016. Biochar horizon 2025. In: Shackley S, Ruysschaert G, Zwart K, Glaser B, editors. Biochar in European Soils and Agriculture: Science. Abingdon: Taylor \& Francis Group, pp. 281-289.

166. Schmidt, H.P., B.H. Pandit, G. Cornelissen \& C.I. Kammann, 2017. Biochar-based fertilization with liquid nutrient enrichment: 21 field trials covering 13 crop species in Nepal. Land Degradation and Development, 28(3):2324-2342. doi: 10.1002/ldr.2652.

167. Schmidt, H.P., A. Anca-Couce, N. Hagemann, C. Werner, D. Gerten, W. Lucht \& C. Kammann, 2018. Pyrogenic carbon capture and storage. GCB Bioenergy, 11(4):573-591. doi: $10.1111 /$ gcbb. 12553 .

168. Schwarzenbach, R.P., T. Egli, T.B. Hofstetter, U. Von Gunten \& B. Wehrli, 2010. Global water pollution and human health. Annu. Rev. Environ. Resour., 35, pp. 109-136.

169. Sha, Z., Q. Li, T. Lv, T. Misselbrook, X. Liu, 2019. Response of ammonia volatilization to biochar addition: a meta-analysis. Science of the Total Environment, 655:1387-1396. doi: 10.1016/j.scitotenv.2018.11.316.

170. Shehata, A.A., W. Schrödl, A.A. Aldin, H.M. Hafez \& M. Krüger, 2012. The effect of glyphosate on potential pathogens and beneficial members of poultry microbiota in 
vitro. Current Microbiology, 66(4):350-358. doi: 10.1007/s00284-012-0277-2. [PubMed] [CrossRef] [Google Scholar]

171. Shi, L., H. Dong, G. Reguera, H. Beyenal, A. Lu, J. Liu, H.Q. Yu \& J.K. Fredrickson, 2016. Extracellular electron transfer mechanisms between microorganisms and minerals. Nature Reviews Microbiology, 14(10):651662. doi: 10.1038/nrmicro.2016.93.

172. Shibamoto, T.K. \& A. Yasuhara, 2007. Dioxin Formation from Waste Incineration. Rev Env. Contam Toxicol, 190, pp. 1-41.

173. Sial, T., Z. Lan, M. Khan, Y. Zhao, F. Kumbhar, J. Liu, A. Zhang, R. Hill, A. Lahori \& M. Mehrunisa, 2019. Evaluation of orange peel waste and its biochar on greenhouse gas emissions and soil biochemical properties within a loss soil. Waste Management. 87. 10.1016/j.wasman.2019.01.042.

174. Silivong, P. \& T.R Preston, 2016. Supplements of water spinach (Ipomoea aquatica) and biochar improved feed intake, digestibility, $\mathrm{N}$ retention and growth performance of goats fed foliage of Bauhinia acuminata as the basal diet. Livestock Research for Rural Development, 28:Article \#113

175. Skutetzky, A. \& E. Starkenstein, 1914. Die neueren Arzneimittel und die pharmakologischen Grundlagen ihrer Anwendung. Berlin: Julius Springer Verlag.

176. Smalley, H.E., H.R. Crookshank \& R.D. Radeleff, 1971. Use of activated charcoal in preventing residues of Ronnel in sheep. Journal of Agricultural and Food Chemistry, 19(2):331-332. doi: 10.1021/ jf60174a015.

177. Sobrova, P., V. Adam, A. Vasatkova, M. Beklova, L. Zeman \& R. Kizek, 2010. Deoxynivalenol and its toxicity. Interdiscip. Toxicol., 3 (3), pp. 94-99.

178. Sohi, S., E. Krull, E. Lopez-Capel \& R. Bol, 2010. A Review of Biochar and Its Use and Function in Soil. Advances in Agronomy. 105: 47-82. 10.1016/S0065-2113(10)050029.
179. Sohi, S., E. Krull, E. Lopez-Capel \& R. Bol, 2010. A Review of Biochar and Its Use and Function in Soil. Advances in Agronomy. 105: 47-82. 10.1016/S0065-2113(10)050029.

180. Sophal, C., D.N. Khang, T.R. Preston \& R.A. Leng, 2013. Nitrate replacing urea as a fermentable $\mathrm{N}$ source decreases enteric methane production and increases the efficiency of feed utilization in Yellow cattle. Livestock Research for Rural Development, 25:Article \#113.

181. Steiner, C., K.C. Das, N. Melear \& D. Lakly, 2010. Reducing nitrogen loss during poultry litter composting using biochar. Journal of Environment Quality, 39(4):1236. doi: 10.2134/jeq2009.0337.

182. Struhsaker, T.T., D.O. Cooney \& K.S. Siex, 1997. Charcoal consumption by Zanzibar red colobus monkeys: its function and its ecological and demographic consequences. International Journal of Primatology, 18(1):61-72. doi: 10.1023/ A:1026341207045. [CrossRef]

183. Struhsaker, T.T., D.O. Cooney \& K.S. Siex, 1997. Charcoal consumption by Zanzibar red colobus monkeys: its function and its ecological and demographic consequences. International Journal of Primatology, 18(1):61-72. doi: 10.1023/ A:1026341207045.

184. Sun, T., B.D.A. Levin, J.J.L. Guzman, A. Enders, D.A. Muller, L.T. Angenent \& J. Lehmann, 2017. Rapid electron transfer by the carbon matrix in natural pyrogenic carbon. Nature Communications, 8(1):14873. doi: 10.1038/ ncomms14873.

185. Sun, T., B.D.A. Levin, J.J.L. Guzman, A. Enders, D.A. Muller, L.T. Angenent \& J. Lehmann, 2017. Rapid electron transfer by the carbon matrix in natural pyrogenic carbon. Nature Communications, 8(1):14873. doi: 10.1038/ ncomms 14873 .

186. Sun, H., H. Zhang, H. Xiao, W. Shi, K. Muller, L.V. Zwieten \& H. Wang, 2019. Wheat straw biochar application increases ammonia 
volatilization from an urban compacted soil giving a short-term reduction in fertilizer nitrogen use efficiency. Journal of Soils and Sediments. 19(4): 1624-1631.

187. Sung, E.I., S.J. You, B.K. Ahn, T.S. Jo, B.J. Ahn, D.H. Choi \& C.W. Kang, 2006. Effects of dietary supplementation of activated charcoal mixed with wood vinegar on broiler performance and antibiotics residue in eggs. Korean Journal of Poultry Science, 33:283293.

188. Tapio, I., T.J. Snelling, F. Strozzi \& R.J. Wallace, 2017. The ruminal microbiome associated with methane emissions from ruminant livestock. Journal of Animal Science and Biotechnology. 2017;8(1):7. doi: 10.1186/ s40104-017-0141-0.

189. Toth, J.D. \& Z. Dou, 2016. Use and impact of biochar and charcoal in animal production systems. In: Guo M, He Z, Uchimiya SM, editors. Agricultural and Environmental Applications of Biochar: Advances and Barriers. Madison: Soil Science Society of America, Inc., pp. 199-224.

190. Uchimiya, M., D.I. Bannon \& L.H. Wartelle, 2012. Retention of heavy metals by carboxyl functional groups of biochars in small arms range soil. J. Agric. Food Chem., 60 (7), pp. 1798-1809.

191. Van Der Zee, F.P., I.A.E. Bisschops, G. Lettinga \& J.A. Field, 2003. Activated carbon as an electron acceptor and redox mediator during the anaerobic biotransformation of azo dyes. Environmental Science \& Technology. 2003;37(2):402-408. doi: 10.1021/ es025885o.

192. Van, D.T.T., N.T. Mui \& I. Ledin, 2006. Effect of method of processing foliage of Acacia mangium and inclusion of bamboo charcoal in the diet on performance of growing goats. Animal feed science and technology, 130(3-4):242-256. doi: 10.1016/ j.anifeedsci.2006.01.008

193. Vaughn, S., J. Kenar, A. Thompson \& S. Peterson, 2013. Comparison of biochars derived from wood pellets and pelletized wheat straw as replacements for peat in potting substrates. Ind. Crops., 51: 437-443. 10.1016/j.indcrop.2013.10.010.

194. Watarai, S. \& Tana, 2005. Eliminating the carriage of Salmonella enterica serovar Enteritidis in domestic fowls by feeding activated charcoal from bark containing wood vinegar liquid (Nekka-Rich) Poultry Science, 84(4):515-521. doi: 10.1093/ps/84.4.515.

195. Watarai, S., Tana \& M. Koiwa, 2008. Feeding activated charcoal from bark containing wood vinegar liquid (nekka-rich) is effective as treatment for cryptosporidiosis in calves. Journal of Dairy Science, 91(4):1458-1463. doi: 10.3168/jds.2007-0406.

196. Werner, C., H.P. Schmidt, D. Gerten, W. Lucht \& C. Kammann, 2018. Biogeochemical potential of biomass pyrolysis systems for limiting global warming to $1.5^{\circ} \mathrm{C}$. Environmental Research Letters, 13(4):044036. doi: 10.1088/1748-9326/ aabb0e.

197. Wild, C.P., J.D. Miller \& J.D. Groopman, 2015. Mycotoxin control in low-and middle-income countries. International Agency for Research on Cancer Lyon, France.

198. Wilson, L.L., D.A. Kurtz, M.C. Rugh, L.E. Chase, J.H. Zieglek, H. Varela-Alvarez \& M.L. Borger, 1971. Effects of feeding activated carbon on growth rate and pesticide concentrations in adipose tissues of steers fed apple waste. Journal of Animal Science, 33(6):1361-1364. doi: 10.2527/ jas 1971.3361361x.

199. Winders, T.M., M.L. Jolly-Breithaupt, H.C. Wilson, J.C. MacDonald, G.E. Erickson \& A.K. Watson, 2019. Evaluation of the effects of biochar on diet digestibility and methane production from growing and finishing steers. Translational Animal Science, 3(2):775-783. doi: 10.1093/tas/txz027.

200. Wittstock, U. \& J. Gershenzon, 2002. Constitutive plant toxins and their role in defense against herbivores and pathogens. Curr. Opin. Plant Biol., 5 (4), pp. 300-307. 
201. Xu, C., H.X. Chen, Q. Xiang, S. Wang, D.Y. Huang \& Y.Z. Zhang, 2018. Effect of peanut shell and wheat straw biochar on the availability of $\mathrm{Cd}$ and $\mathrm{Pb}$ in a soil-rice (Oryza sativa L.) system. Environ Sci Pollut Res Int. 25(2):1147-1156. doi: 10.1007/s11356017-0495-z. Epub 2017 Oct 27.

202. Yamauchi, K., N. Manabe, Y. Matsumoto K. Yamauchi, 2013. Increased collagen accumulation in eggshell membrane after feeding with dietary wood charcoal powder and vinegar. Connect. Tissue Res., 54 (6), pp. 416-425.

203. Yamauchi, K., J. Ruttanavut \& S. Takenoyama, 2010. Effects of dietary bamboo charcoal powder including vinegar liquid on chicken performance and histological alterations of intestine. J. Anim. Feed Sci., 19 (2), pp. $257-$ 268.

204. Yoshimura, H., H. Kamimura, K. Oguri, Y. Honda \& M. Nakano, 1986. Stimulating effect of activated charcoal beads on fecal excretion of $2,3,4,7,8$ -

pentachlorodibenzofuran in rats. Chemosphere, 15(3):219-227. doi: 10.1016/ 0045-6535(86)90017-2.

205. Yu L., Y. Yuan, J. Tang, Y. Wang \& S. Zhou, 2015. Biochar as an electron shuttle for reductive dechlorination of pentachlorophenol by Geobacter sulfurreducens. Scientific Reports, 5(1):1-10. doi: 10.1038/srep16221.

206. Yu L., Y. Yuan, J. Tang, Y. Wang \& S. Zhou, 2015. Biochar as an electron shuttle for reductive dechlorination of pentachlorophenol by Geobacter sulfurreducens. Scientific Reports, 5(1):1-10. doi: 10.1038/srep16221. [

207. Zainal, H., R. Bachmann \& S.K. Loh, 2016. Production and Characterization of Biochar from Palm Kernel Shell (PKS). Conference: 4th Asian Conference on Biomass Science, At Universiti Sains Malaysia, Bayan Lepas Penang. 
